\title{
Criteria of the German Consortium for Hereditary Breast and Ovarian Cancer for the Classification of Germline Sequence Variants in Risk Genes for Hereditary Breast and Ovarian Cancer
}

\section{Kriterien des Deutschen Konsortiums Familiärer Brust- und Eier- stockkrebs zur Klassifizierung von Keimbahn-Sequenzvarianten in Risikogenen für familiären Brust- und Eierstockkrebs}

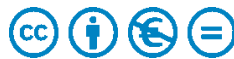

Authors

Barbara Wappenschmidtt ${ }^{1}$, Jan Hauke ${ }^{1}$, Ulrike Faust ${ }^{2}$, Dieter Niederacher ${ }^{3}$, Lisa Wiesmüller ${ }^{4}$, Gunnar Schmidtt $^{5}$, Evi Groß $^{6}$, Andrea Gehrig ${ }^{7}$, Christian Sutter ${ }^{8}$, Juliane Ramser ${ }^{9}$, Andreas Rump ${ }^{10}$, Norbert Arnold ${ }^{11,12}$, Alfons Meindl ${ }^{6,9}$

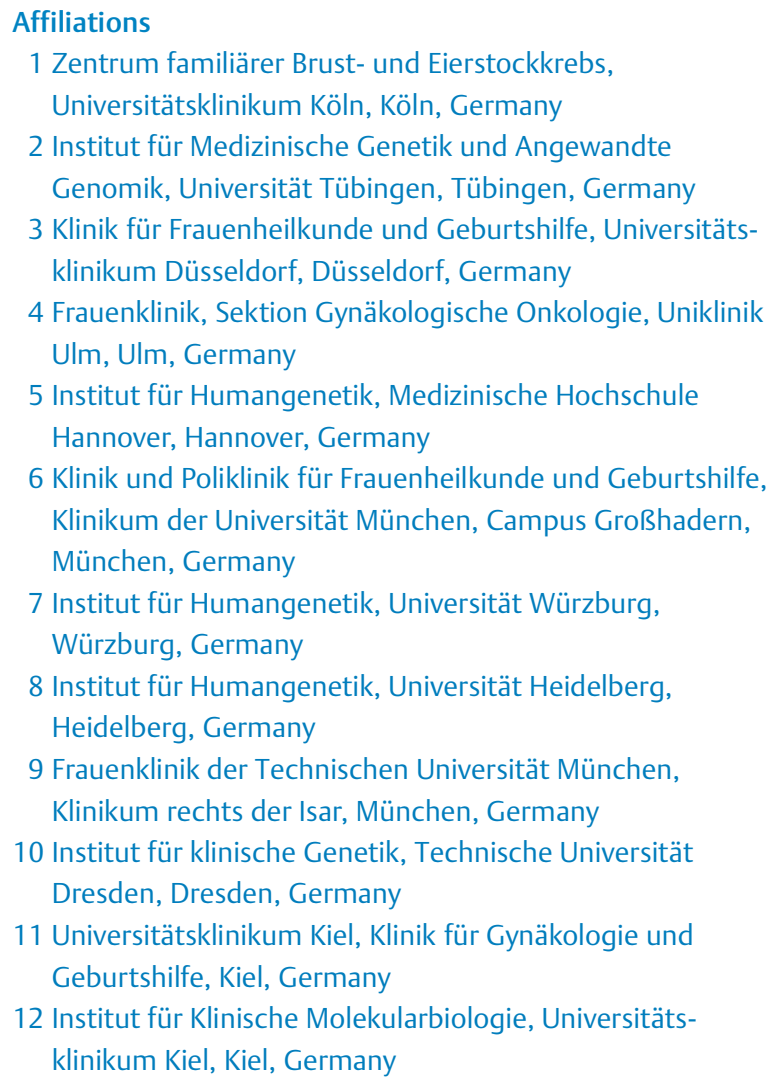

Key words

hereditary breast/ovarian cancer, classification of genetic variants, risk genes

Schlüsselwörter

familiärer Brust-Eierstockkrebs, Klassifikation genetischer Varianten, Risikogene
received $\quad 19.11 .2019$
revised 28.1.2020
accepted 29.1.2020

Bibliography

DOI https://doi.org/10.1055/a-1110-0909

Geburtsh Frauenheilk 2020; 80: 410-429 @ Georg Thieme

Verlag KG Stuttgart · New York | ISSN 0016-5751

Correspondence

Norbert Arnold

Universitätsklinikum Kiel, Klinik für Gynäkologie

und Geburtshilfe

Arnold-Heller-Straße 3, Haus U18, 24105 Kiel, Germany

Norbert.Arnold@uksh.de

A Deutsche Version unter:

https://doi.org/10.1055/a-1110-0909

\section{ABSTRACT}

More than ten years ago, the German Consortium for Hereditary Breast and Ovarian Cancer (GC-HBOC) set up a panel of experts (VUS Task Force) which was tasked with reviewing the classifications of genetic variants reported by individual centres of the GC-HBOC to the central database in Leipzig and reclassifying them, where necessary, based on the most recent data. When it evaluates variants, the VUS Task Force must arrive at a consensus. The resulting classifications are recorded in a central database where they serve as a basis for ensuring the consistent evaluation of previously known and newly identified variants in the different centres of the GC-HBOC. The standardised VUS evaluation by the VUS Task Force is a key element of the recall system which has also been set up by the GC-HBOC. The system will be used to pass on 
information to families monitored and managed by GC-HBOC centres in the event that previously classified variants are reclassified based on new information. The evaluation algorithm of the VUS Task Force was compiled using internationally established assessment methods (IARC, ACMG, ENIGMA) and is presented here together with the underlying evaluation criteria used to arrive at the classification decision using a flow chart. In addition, the characteristics and special features of specific individual risk genes associated with breast and/or ovarian cancer are discussed in separate subsections. The URLs of relevant databases have also been included together with extensive literature references to provide additional information and cover the scope and dynamism of the current state of knowledge on the evaluation of genetic variants. In future, if criteria are updated based on new information, the update will be published on the website of the GC-HBOC (https://www.konsortium-familiaerer-brustkrebs.de/).

\section{ZUSAMMENFASSUNG}

Das Deutsche Konsortium für Familiären Brust- und Eierstockkrebs (GC-HBOC) etablierte vor über 10 Jahren eine Expertengruppe (VUS Task Force), um die von den einzelnen Zentren des GC-HBOC an die zentrale Datenbank in Leipzig gemeldeten Varianten hinsichtlich ihrer Klassifizierung zu überprüfen und ggf. nach aktueller Datenlage neu einzustufen. Die innerhalb der VUS-Task Force konsentierten Variantenbewertun- gen und resultierenden -klassifizierungen werden in einer zentralen Datenbank hinterlegt und sind als Grundlage zu berücksichtigen, um eine einheitliche Bewertung bereits bekannter wie auch neu identifizierter Varianten innerhalb der verschiedenen Zentren des GC-HBOC zu gewährleisten. Die standardisierte VUS-Bewertung durch die VUS Task Force ist ein zentrales Element des vom GC-HBOC ebenfalls etablierten Recall-Systems. Dieses dient der Weitergabe der Informationen an die in den Zentren betreuten Familien im Falle einer aufgrund neuer Erkenntnisse aktualisierten Neubewertung von bereits klassifizierten Varianten. Die in Anlehnung an international etablierte Bewertungsverfahren (IARC, ACMG, ENIGMA) angepassten Bewertungsalgorithmen der VUS Task Force werden in diesem Artikel anhand der zugrundeliegenden Entscheidungskriterien präsentiert, die gemäß eines priorisierenden Fließschemas zum Klassifizierungsergebnis führen. Weiterhin werden genspezifische Regelungen und Besonderheiten, die für einzelne mit Brust- und/oder Eierstockkrebs assoziierte Risikogene zu berücksichtigen sind, in einzelnen Unterkapiteln dargelegt. Um dem Umfang und der Dynamik des aktuellen Wissens zur Variantenbewertung gerecht zu werden, sind neben umfangreichen Literaturverweisen insbesondere auch die URLs von relevanten Datenbanken angegeben. In Zukunft sollen an neue Erkenntnisse angepasste Kriterien auf der Webseite von GC-HBOC (https://www. konsortium-familiaerer-brustkrebs.de/) veröffentlicht werden.

\section{General Principles}

The criteria of the German Consortium for Hereditary Breast and Ovarian Cancer (http://www.konsortium-familiaerer-brustkrebs. $\mathrm{de} /$ ) for the classification of germline sequence variants in risk genes for hereditary breast and ovarian cancer were developed and compiled by the members of the panel of experts on variant evaluation (VUS Task Force) from the German Consortium for Hereditary Breast and Ovarian Cancer listed above. The task of this panel of experts is to specify binding criteria for the German Consortium for Hereditary Breast and Ovarian Cancer to evaluate variants and verify the classification of variants to ensure that variants are uniformly evaluated by the Consortium. The present criteria are based on the IARC ${ }^{1}$ 5-class system for high-risk genes ${ }^{2}$ which is based on the guidelines issued by the ENIGMA ${ }^{3}$ Consortium (ENIGMA BRCA1/2 Classification Criteria, Version 2.5.1, June 2017), as well as the $A C M C^{4}$ and $A_{C G S}^{5}$ guidelines. Using this 5-class system, germline sequence variants are evaluated in terms of their relevance for a loss of function of the coded protein
(Class1: neutral, Class2: likely neutral, Class3: uncertain evidence/no reliable evaluation, Class4: likely relevant loss of function, Class5: relevant loss of function; level of significance, see [4]). For high-penetrance genes (such as BRCA1, BRCA2) for which a clinical correlation (pathogenicity) with loss of function has been described, the functional classification yields a pathogenicity evaluation based on the IARC 5-class system (ranging from Class 1: not pathogenic to Class5: pathogenic), as outlined in Appendix A 2, - Table 1. The advantage of such a structured approach is that it starts by checking for defined criteria which can be used for a quick and unambiguous classification, and the extensive data and literature search is only carried out afterwards (see Appendix A 2, > Table 2: Relevant literature and databases, and A 3, Fig. 1: Evaluation criteria flow chart). As regards the classification of sequence variants of the genes ATM, BRCA1, BRCA2, BRIP1, CDH1, CHEK2, PALB2, RAD51C, RAD51D and TP53, all of them so-called "core genes" according to the TruRisk panel (version 1/2018, see the homepage of the German Consortium: http://www.konsortium-familiaerer-brustkrebs.de/), the specific

\footnotetext{
International Agency for Research on Cancer.

High-risk genes: at least one sequence variant with an odds ratio for breast and/or ovarian cancer of $>5$

(e.g. BRCA1, BRCA2, RAD51C, PALB2, TP53, ATM), see [1,2].

Evidence-based network for the interpretation of germline mutant alleles: http://enigmaconsortium.org/

American College of Medical Genetics and Genomics (ACMG [3]).

Association for Clinical Genomic Science (ACGS, http://www.acgs.uk.com/).
} 
features of the individual genes listed in Appendix A 5 must be taken into account. Moderate/low-penetrance genes are only evaluated in terms of their functionality (in these cases: loss of function should not be equated with "pathogenicity"). Even variants of high-risk genes may only be associated with an intermediate risk $[5,6]$.

\section{Criteria for the Interpretation of mRNA Analyses}

The criteria of the German Consortium for Hereditary Breast and Ovarian Cancer for the evaluation of sequence variants with subsequent mRNA analysis are based on the guidelines of the ENIGMA Consortium (see also [7]). The respective threshold values of potential splice variants for an empirical predictive prognosis based on three commonly used predictive programmes are given in Appendix A 1. Appendix A 4 ( $\triangleright$ Fig. 2) gives a schematic representation of the areas considered by the VUS Task Force when evaluating the splice variants. mRNA analysis is carried out using fresh blood samples, cultured lymphocytes, cultured lymphoblastoid cell lines, etc. and compared in parallel with at least 5 controls of the same type of material. A sequence variant is described as pathogenic if it has the following effect on mRNA transcription: one or more aberrant transcripts of the variant allele are detected, which lead to a stop codon or an in-frame deletion and result in the destruction of known functional domains. Sequencing of the full-length transcript of the variant allele or the presence of an intronic variant of a cis-acting polymorphism is considered sufficient (evidence of monoallelic expression) to determine the transcript amount (using semi-quantitative or quantitative methods). Variants which show a transcript pattern comparable to the mean value of controls are rated as neutral/not pathogenic due to the lack of aberrant mRNA. As regards the cDNA primer design, the physiological splice variants/naturally occurring isoforms must also be taken into account (see [8,9]).

Caution: Certain BRCA1 and BRCA2 variants which are $\pm 1,2$ bp from the exon border and which are predicted or proven to lead to at least $20-30 \%$ naturally occurring in-frame RNA isoforms per allele could presumably result in some residual protein activity (see [9-12]) and are therefore classified as VUS Class3, unless there is evidence to the contrary (see Overview, Appendix 5, > Table 5)

\section{Approach of the VUS Task Force}

The Consortium recommends routinely testing for 10 genes which are known (as per 8/19) to be associated with breast and/ or ovarian cancer: ATM, BRCA1, BRCA2, BRIP1, CDH1, CHEK2, PALB2, RAD51C, RAD51D and TP53 (http://www.konsortiumfamiliaerer-brustkrebs.de/).

The Consortium's panel of experts (VUS Task Force) holds monthly telephone conferences and, if necessary, meetings to reach a consensus on the classification of newly reported sequence variants, discuss any new evidence available for the reevaluation of already known variants, and evaluate variants of unclear significance. In the event of a re-evaluation, the central database of the Consortium will inform all centres about the reclassification (recall system).
It should be expressly noted that new information can lead to changes in the classification of variants and that these classifications are regularly reviewed by the panel of experts. Similarly, new findings can lead to changes in the list of core genes for which the German Consortium for Hereditary Breast and Ovarian Cancer recommends that patients are tested. All such changes along with the inclusion of new findings into the classification are published on the homepage of the German Consortium for Hereditary Breast and Ovarian Cancer (http://www. konsortium-familiaerer-brustkrebs.de/).

\section{Classification of Sequence Variants According to Their Functional Relevance}

\section{Class1 (functionally irrelevant/no loss of function) if one of} the following criteria is met:

1.1 Allele frequency of variants in large population groups (e.g. Caucasians, Africans, or Asians) is $\geq 1 \%$ (minor allele frequency $[\mathrm{MAF}] \geq 0.01$ ). Caution: An allele frequency of $\geq 1 \%$ in subpopulations with a low-diversity gene pool (examples: Finnish population, founder mutations!) is not sufficient.

1.2 Variants with a calculated multifactorial probability of $<0.001$ of being pathogenic.

Caution: This currently only applies to the high-risk genes BRCA1/2 (for an exemplary calculation, see [13]).

1.3 Variants in high-risk genes which occur in at least 10 individuals in appropriate cohorts of persons without disease ( $\triangleright$ Table 1).

2. Class2 (probably no loss of function/functionally irrelevant) if one of the following criteria are met:

2.1 Allele frequency of variants in large population groups (e.g. Caucasians, Africans, or Asians) is $0.5-1 \%$ (MAF $0.005-0.01)$ Caution: An allele frequency of $0.5-1 \%$ in subpopulations with a low-diversity gene pool (examples: Finnish population, founder mutations!) is not sufficient.

2.2 Exonic variants (A) which result in substitution of an amino acid (missense variants) or small in-frame insertions/deletions (insertions/deletions of one or fewer amino acid [s]) and whose a priori probability of pathogenicity is $\leq 2 \%$ (A-GVGD analysis, http://priors.hci.utah.edu/PRIORS/); intronic variants (B) which are more than $-20 \mathrm{bp},+10 \mathrm{bp}$ from the exon border; and synonymous variants $(C)$ if these variants $(A-C)$ will, according to bioinformatic prediction programmes (see Appendix A 1), in all probability not change the splicing mechanism. In non-BRCA1/2 genes, the above-mentioned variants must be present in large population groups with an allele frequency of 0.001 $\leq \mathrm{MAF}<0.01$.

2.3 Synonymous substitutions or intronic variants which show no mRNA aberrations in the form of exon deletions/duplications or monoallelic expression of the wildtype (wt) transcript in "in-vitro" laboratory tests even if, according to bioinformatic prediction programmes (see Appendix A 1 for programmes and threshold values), in all probability they change the splicing mechanism. 
2.4 Variants which occur in the same gene with a clearly pathogenic variant in trans (co-occurrence), if it has been verified that a homozygous or compound heterozygous genotype is associated with a known, clinically unambiguous phenotype.

2.5 Variants with a calculated multifactorial probability of pathogenicity of 0.001-0.049.

Caution: This currently only applies to the high-risk genes BRCA1/2 (for an exemplary calculation, see: [13]).

2.6 Exon variants which code for the same amino acid exchange as a sequence variant which has already been classified as Class 1 but are based on a different nucleotide exchange if no aberrant splicing is predicted.

2.7 Missense variants for which information from functional analyses, etc., is available but not sufficient for multifactorial classification and which have been classified as Class2 by a panel of experts (e.g. ENIGMA).

3. Class3 (unclear functional relevance) if one of the following criteria is met: variants which cannot be unambiguously assigned to Class1, Class2, Class4, or Class5, e.g.:

3.1 Special cases which could be assigned to one of the other classes based on the evaluation criteria but are listed in Appendix A 5 among the characteristics of individual core genes or in Table 5, Appendix of BRCA1/2 classification criteria, Version 2.5.1, July 2017 (ENIGMA) ( Table 5).

3.2 Variants where the data used for their evaluation is contradictory and for which further studies are still required.

3.3 Variants which are $-\mathbf{2 0} \mathrm{bp},+\mathbf{1 0} \mathrm{bp}$ from the exon border and which, based on bioinformatic predictive programmes (see Appendix A 1), probably change the splicing mechanism as long as no in-vitro mRNA analysis has been done yet ( $\triangleright$ Fig. 2, Schematic representation of variants in the vicinity of splice sites).

3.4 Exon duplications which have not been analysed further (e.g. break point analysis, cDNA analysis, etc.).

3.5 Variants with a calculated multifactorial probability of pathogenicity of 0.05-0.949.

Caution: This currently only applies to the high-risk genes $B R C A 1 / 2$ (for an exemplary calculation, see [13]).

4. Class4 (probable loss of function/functionally relevant) if one of the following criteria is met:

4.1 Variants with a calculated multifactorial probability of pathogenicity of 0.95-0.99.

Caution: This currently only applies to the high-risk genes BRCA1/2 (for an exemplary calculation, see Goldgar et al., 2004 [13]).

4.2 Variants which code for a premature termination of protein biosynthesis (nonsense or frameshift variants) and do not necessitate the loss of known clinically relevant functional protein domains as long as the location of the stop codon is not downstream from the Nonsense-mediated decay(NMD-)relevant site, 50 base pairs before the end of the penultimate exon.

4.3 Intronic variants in position $\pm 1,2$ or $G>$ non- $G$ in the last position of the exon: if there is a positive splicing prediction (see Appendix A 1) and the first 6 bases in the intron are not GTRRGT and an aberrant in-vitro mRNA analysis is not yet available (i.e. has not [yet] been confirmed by a panel of experts or the pathomechanism of loss of function has been confirmed to be exon skipping or allele-specific transcript expression).

\section{Exceptions:}

- A cryptic splice site (AG/GT) in the vicinity is activated and the (predicted) new exon is spliced in-frame ( $\rightarrow$ Class 3 )

- The (predicted) skipped exon (or exons) is alternatively spliced in significant quantities ( $\rightarrow$ Class3).

- The (predicted) skipped exon (or exons) is spliced in-frame and contains no known functional domain ( $\rightarrow$ Class 3 )

4.4 Variants which code for the same amino acid exchange as pathogenic missense variants which have already been categorised as Class5 but are caused by another nucleotide exchange and for which there is no positive splicing prediction (see Appendix A 1).

4.5 In-frame deletions (even for just one amino acid) which lead to the loss of a missense variant already categorised as Class 5 and which result in the interruption of known, functionally important domains.

4.6 Extensive in-frame deletions which lead to the interruption/loss of known, functionally important domains.

4.7 In-frame insertions verified by in-vitro mRNA analysis which result in the interruption of functionally important domains.

4.8 Variants which lead to mutations of the translation initiation codon (AUG, methionine) and for which there is no evidence (e.g. an alternative start codon in the immediate vicinity) which would support an alternative classification.

4.9 Variants for which information from functional analyses, clinical data, etc., is available but insufficient for a multifactorial classification and which are categorised as Class4 by a panel of experts (e.g. ENIGMA).

5. Class5 (loss of function/functionally relevant) if one of the following criteria are met:

5.1 Variants which code for a premature termination of protein biosynthesis (nonsense or frameshift variants) which prevents the expression of known, clinically relevant, functional protein domains.

5.2 Variants with a calculated multifactorial probability of pathogenicity of $>0.99$.

Caution: This currently only applies to the high-risk genes $B R C A 1 / 2$ (for an exemplary calculation, see Goldgar et al., 2004 [13]).

5.3 Splice variants for which a frameshift effect was established by in-vitro mRNA analysis, which leads to a premature termination of protein biosynthesis and prevents the expression of known, clinically relevant, functional protein domains and for which a wild-type transcript of the mutated allele has not been confirmed (monoallelic expression).

5.4 Splice variants for which in-vitro mRNA analysis detected an in-frame deletion/insertion which leads to the interruption or loss of a known, clinically relevant domain or functional inactivation through changes of the protein struc- 
ture and for which a wild-type transcript of the mutated allele has not been verified (monoallelic expression).

5.5 Copy-number deletion variants which result in the interruption or loss of one or more exons with known, clinically relevant functional domains or lead to a reading frameshift, which results, according to the prediction, in the inactivation of known, clinically relevant, functional domains.

5.6 Copy-number duplication variants of any size, confirmed by laboratory analysis, which duplicate one or more exons and lead to a reading frameshift, which results, according to the prediction, in the inactivation of known, clinically relevant, functional domains.

\section{Appendix}

\section{A 1. Splicing prediction programmes and their threshold values}

The splicing prediction programmes MaxEntScan (MES), Splice Site Finder (SSF), and Human Splicing Finder (HSF) are considered relatively reliable and should therefore be used to evaluate possi- ble effects on the splicing process. MaxEntScan results are considered non-normal for a deviation of delta of $\geq 15 \%$ [14], Human Splicing Finder for a delta of $\geq 4.1 \%$ [10] and Splice Site Finder for a deviation of delta of $\geq 5 \%$ [14]. An mRNA analysis should be done for evaluation in cases with non-normal prediction (at least two of the three programmes mentioned below). The precondition is that the physiological splice site is recognised by the respective prediction software based on the following threshold values.

The threshold values (calculated for BRCA1/2 [14]) are:

1. MES $>3$

2. $S S F>60$

3. $\mathrm{HSF}>80$

An approximation of these threshold values can also be for the other genes. Once specific threshold values have been defined, then the defined threshold values must be used.

\section{A 2.}

- Tables 1 and 2 .

- Table 1 IARC 5-tiered classification system with accompanying recommendations for family management ${ }^{\mathrm{a}}$ (excerpt from https://enigmaconsortium. org/wp-content/uploads/2018/10/ENIGMA_Rules_2017-06-29-v2.5.1.pdf).

\begin{tabular}{|c|c|c|c|c|}
\hline Class & $\begin{array}{l}\text { Quantitative measure: } \\
\text { probability of patho- } \\
\text { genicity }\end{array}$ & $\begin{array}{l}\text { Predictive testing } \\
\text { of at-risk relatives }\end{array}$ & Surveillance of at-risk relatives & $\begin{array}{l}\text { Research testing } \\
\text { of relatives }\end{array}$ \\
\hline 5: Pathogenic & $>0.99$ & Yes & Full high-risk guidelines for variant carriers & Not indicated \\
\hline 4: Likely pathogenic & $0.95-0.99$ & Yes $^{b}$ & Full high-risk guidelines for variant carriers & Yes \\
\hline 3: Uncertain & $0.05-0.949$ & $\mathrm{No}^{\mathrm{b}}$ & Based on family history \& other risk factors & Yes \\
\hline $\begin{array}{l}\text { 2: Likely not pathogenic or } \\
\text { of little clinical significance }\end{array}$ & $0.001-0.049$ & $\mathrm{No}^{\mathrm{b}}$ & $\begin{array}{l}\text { Based on family history \& other risk factors - } \\
\text { treat as "no BRCA1/2 pathogenic variant } \\
\text { detected" for this disorder }\end{array}$ & Yes \\
\hline $\begin{array}{l}\text { 1: Not pathogenic or } \\
\text { of no clinical significance }\end{array}$ & $<0.001$ & $\mathrm{No}^{\mathrm{b}}$ & $\begin{array}{l}\text { Based on family history \& other risk factors - } \\
\text { treat as "no BRCA } 1 / 2 \text { pathogenic variant } \\
\text { detected" for this disorder }\end{array}$ & Not indicated \\
\hline \multicolumn{5}{|c|}{ a Adapted for clarity from the original published tabular presentation (Plon et al., 2008 [4]) } \\
\hline
\end{tabular}


- Table 2 Relevant literature and databases available for evaluation.

\section{Database}

1000Genomes

ARUP (BRCA1)

$\operatorname{ARUP}(B R C A 2)$

BIC (Breast Cancer Information Core)

BRCA1 CIRCOS (via BIC, or Caution: specify BIC nomenclature!)

BRCA Exchange

ClinVar (ClinGen)

Database of Functional Classifications of BRCA1 Variants

based on Saturation Genome Editing [15, 16]

dbSNP

EVS/ESP

Exome Aggregation Consortium ExAC Browser

exUV-LOVD (multifactorial analysis of reclassified BRCA1/2 variants)

FLOSSIES (Fabulous Ladies Over Seventy: germline variants

for 27 breast cancer-relevant genes in approx. 10000 women

aged $>70$ years, who have not developed cancer to date)

Genome Aggregation Database GnomAD

Google Scholar

HGMD Professional (registration required)

IARC TP53 database

InSiGHT Consortium (classification database)

KAVIAR (Known VARiants, genomic)

LOVD (Leiden Open Variation Database, general)

LOVD database, ATM

LOVD database, BRCA1

LOVD database, $B R C A 2$

LOVD database, BRIP1

LOVD database, $\mathrm{CDH} 1$

LOVD database, CHEK2

LOVD database, PALB2

LOVD database, RAD51C

LOVD database, RAD51D

LOVD database, TP53

PubMed

TP53, PHANTM (genotype/phenotype correlation)

UMD (Univ. Mutation Database, LSDB: Locus Specific Databases)

UMD/BRCAshare-BRCA1 (registration required)

UMD/BRCAshare-BRCA2 (registration required)

UMD TP53

VarSeak

VarSome (automated ACMG classification)
URL

http://www.1000genomes.org/

http://arup.utah.edu/database/BRCA/Variants/BRCA1

http://arup.utah.edu/database/BRCA/Variants/BRCA2

http://research.nhgri.nih.gov/bic/

https://research.nhgri.nih.gov/projects/bic/circos/search.shtml

http://brcaexchange.org

https://www.ncbi.nlm.nih.gov/clinvar/

https://sge.gs.washington.edu/BRCA1/

https://www.ncbi.nlm.nih.gov/snp

http://evs.gs.washington.edu/EVS/

http://exac.broadinstitute.org/

http://hci-exlovd.hci.utah.edu/home.php

https://whi.color.com/

http://gnomad.broadinstitute.org/

http://scholar.google.de/

https://portal.biobase-international.com/

http://p53.iarc.fr/

http://www.insight-database.org/classifications/

http://db.systemsbiology.net/kaviar/cgi-pub/Kaviar.pl

http://www.lovd.nl/3.0/home

https://databases.lovd.nl/shared/genes/ATM

https://databases.lovd.nl/shared/genes/BRCA1

https://databases.lovd.nl/shared/genes/BRCA2

http://databases.lovd.nl/shared/genes/BRIP1

http://databases.lovd.nl/shared/genes/CDH1

https://databases.lovd.nl/shared/genes/CHEK2

http://databases.lovd.nl/shared/genes/PALB2

https://databases.lovd.nl/shared/genes/RAD51C

https://databases.lovd.nl/shared/genes/RAD51D

https://databases.lovd.nl/shared/genes/TP53

http://www.ncbi.nlm.nih.gov/pubmed/

http://mutantp53.broadinstitute.org/heatMap/login

http://www.umd.be/

http://www.umd.be/BRCA1/

http://www.umd.be/BRCA2/

http://p53.fr/tp53-database

https://varseak.bio/

https://varsome.com/ 


\section{A 3. Evaluation Criteria Flow Chart}

- Fig. 1.

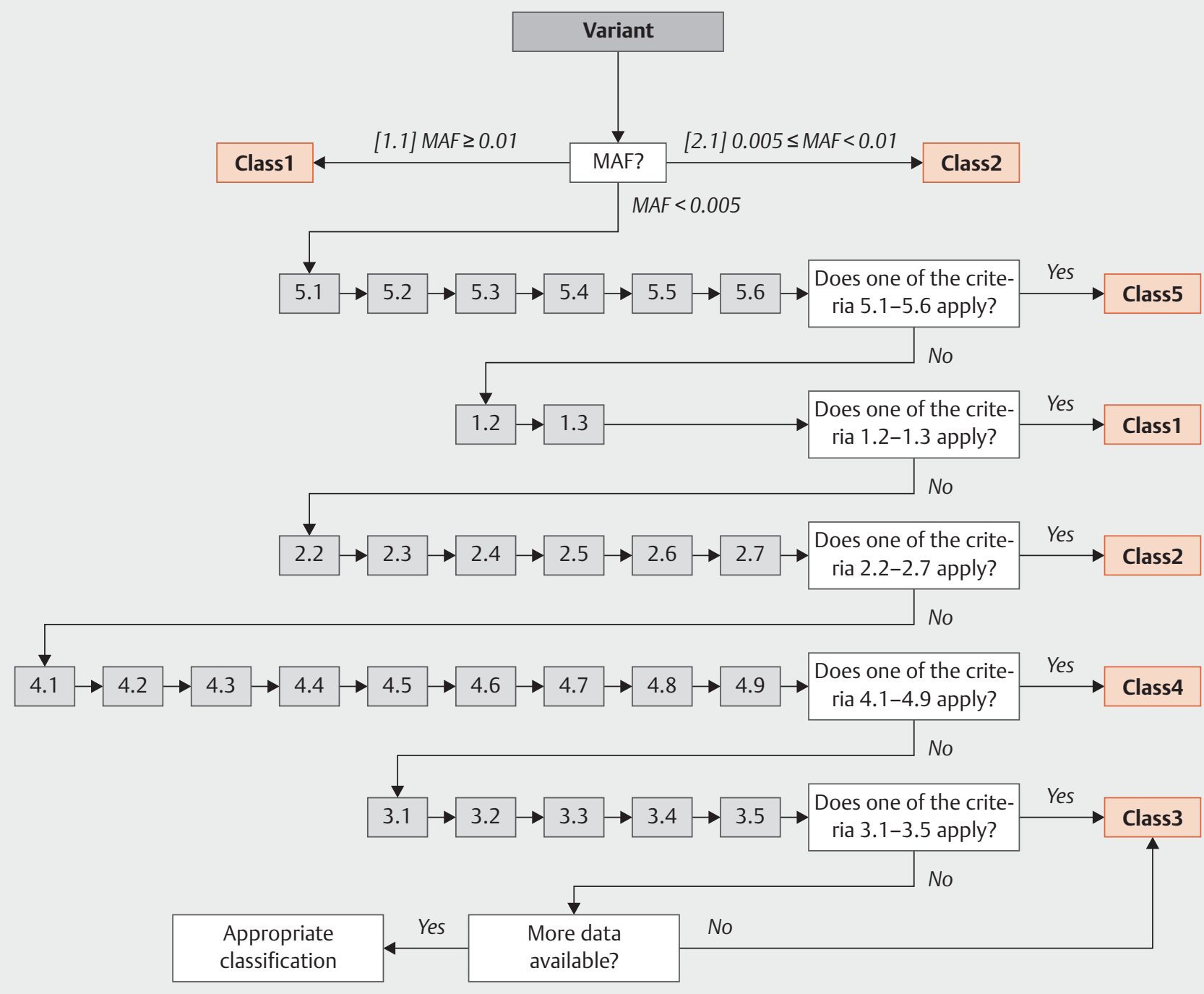

- Fig. 1 VUS evaluation criteria 1.1. 


\section{A 4. Schematic Representation of Variants in the Vicinity of Splice Sites}

> Fig. 2.

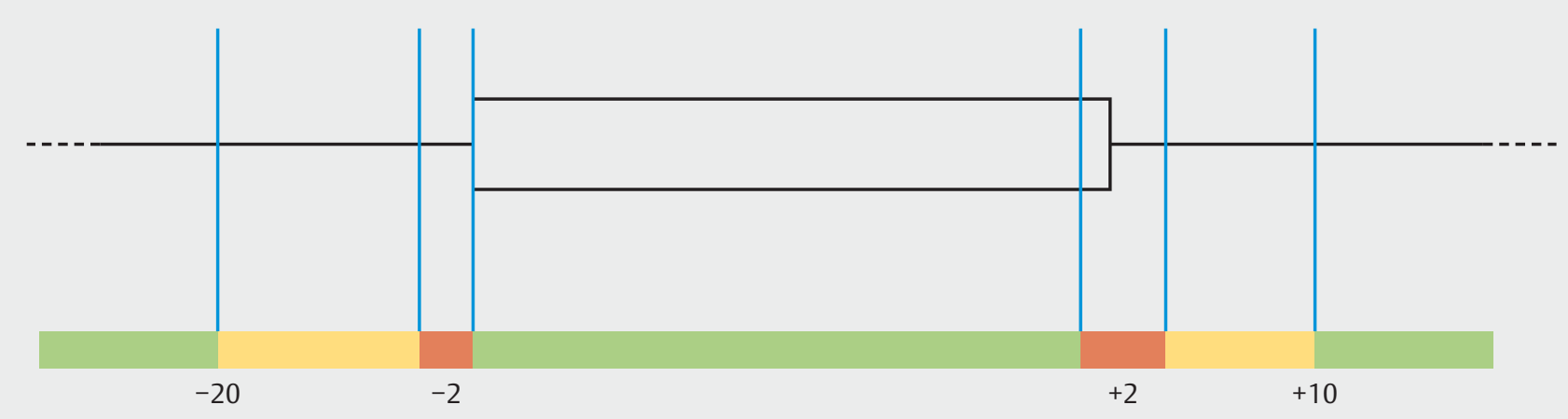

1. Intronic variants at a distance of more than $-20 /+10$ from the exon if the splicing prediction is normal: Class2.

2. Exonic (synonymous) variants if the splicing prediction is normal and MAF $\geq 0.001$ but $<0.01$ : Class 2 .

3. In both cases: if the splicing prediction is abnormal: Class3 and RNA analysis is required.

Variants in this region should be investigated using RNA analysis, particularly if the splicing prediction is abnormal: Class3.

Intronic variants at position $-1,-2 /+1,+2$ or $\mathrm{G}>\neq \mathrm{G}$ at the last position of the exon: if the splicing prediction is positive and the first 6 bases in the intron are not GTRRGT even without an RNA analysis: Class4.

All other variants at these positions: initially Class3, RNA analysis (according to the Consortium) necessary/obligatory!

In addition, synonymous substitutions or intronic variants with an abnormal splicing prediction but which have no mRNA aberrations in the form of exon deletions/duplications or monoallelic expression of the wt transcript in "in-vitro" laboratory tests: Class1.

Fig. 2 Classification of variants which can affect splicing.

The use of predictive programmes to assess possible splicing effects is obligatory for all new mutations including stop mutations as "rescue" effects can occur through alternative transcripts.

\section{A 5. Characteristics of Individual Genes}

The above-mentioned general evaluation criteria should apply to all genes. However, some exceptions, variations and special features are present in specific variants and regions of individual genes, which, for the sake of clarity, are listed below.

\section{A 5.1 BRCA1/2}

The following should be categorised as Class3: truncating BRCA1 mutations after the amino acid position 1854 and truncating $B R C A 2$ variants after amino acid position 3308 (they are not categorised as Class1, as structural mutations cannot be excluded). Exception: truncating variants after the polymorphic stop codon p.(Lys3326*) are classified as dispensable/neutral (Class1) [17] and ENIGMA: p.(Lys3326*) is a frequently detected polymorphism which is not associated with a higher risk, OR 1.3-1.5 depending on breast or ovarian cancer. This means that variants which lead to a stop downstream from p.(Lys3326*) will also not be associated with an increased risk of developing disease.
The following should be categorised as Class5 in BRCA1/2: all truncating BRCA1 variants up to the last mutation unequivocally identified as pathogenic at amino acid position 1853 [18] and all truncating BRCA2 variants up to amino acid position 3308, c.9924C>G [19]. See ENIGMA BRCA1,2 functional domains, \ Tables 3 and 4. Caution: Be aware of the potential impact of NMD; the last $50 \mathrm{bp}$ in the penultimate exon and variants in the last exon usually are usually not subject to NMD. The predictive value of RNA analysis of blood may be limited as it does not involve the target tissue.

Other special features are listed in the Appendix of the evaluation guidelines of the ENIGMA Consortium, which can be accessed via the following link: https://enigmaconsortium.org/wp-content/ uploads/2018/10/ENIGMA_Rules_2017-06-29-v2.5.1.pdf, Tables 3, 4 and 6 ( $\vee$ Tables 3 to 5 ). 
> Table 3 Excerpt from https://enigmaconsortium.org/wp-content/uploads/2018/10/ENIGMA_Rules_2017-06-29-v2.5.1.pdf.

Table 3: Catalogue of BRCA1 conserved domains/motifs and currently known, clinically important amino acid residues, and relevance for classification of BRCA1 in-frame and terminal exon sequence variants.

\begin{tabular}{|c|c|c|c|c|c|}
\hline $\begin{array}{l}\text { Domain/ } \\
\text { Motif }\end{array}$ & $\begin{array}{l}\text { AA } \\
\text { start }\end{array}$ & $\begin{array}{l}\text { AA } \\
\text { end }\end{array}$ & $\begin{array}{l}\text { AA alterations with demonstrated } \\
\text { clinical importance }^{\mathrm{a}}\end{array}$ & $\begin{array}{l}\text { Classification of } \\
\text { in-frame dele- } \\
\text { tions targeting } \\
\text { domain/motifs }\end{array}$ & References and summary interpretation ${ }^{a}$ \\
\hline RING & 1 & 101 & $\begin{array}{l}\text { L22S (c.65T>C [p.Leu22Ser]) } \\
\text { T37K (c.110C>A [p.Thr37Lys]) } \\
\text { C39R (c.115T>C [p.Cys39Arg]) } \\
\text { H41R (c.122A>G [p.His41Arg]) } \\
\text { C44S (c.130T>A [p.Cys44Ser]) } \\
\text { C44Y (c.131G>A [p.Cys44Tyr]) } \\
\text { C61G (c.181T>G [p.Cys61Gly]) }\end{array}$ & $\begin{array}{l}\text { Class5 if at least } \\
\text { one clinically rel- } \\
\text { evant residue is } \\
\text { removed. Other- } \\
\text { wise Class3. }\end{array}$ & $\begin{array}{l}\text { http://www.ncbi.nlm.nih.gov/protein/15988069; } \\
\text { http://hci-exlovd.hci.utah.edu; multifactorial analysis } \\
\text { for H41R (c.122A>G [p.His41Arg]) (Whiley et al., 2014). }\end{array}$ \\
\hline NES & 81 & 99 & None reported & Class3 & $\begin{array}{l}\text { Domain location description (Rodriguez and Henderson, } \\
\text { 2000). }\end{array}$ \\
\hline NLS1 & 503 & 508 & None reported & Class3 & $\begin{array}{l}\text { Domain location description (Chen et al., 1996, Thakur } \\
\text { et al., 1997). }\end{array}$ \\
\hline NLS2 & 607 & 614 & None reported & Class3 & $\begin{array}{l}\text { Domain location description (Chen et al., 1996, Thakur } \\
\text { et al., 1997). }\end{array}$ \\
\hline NLS3 & 651 & 656 & None reported & Class3 & Domain location description (Chen et al., 1996). \\
\hline $\begin{array}{l}\text { COILED- } \\
\text { COIL }\end{array}$ & 1391 & 1424 & None reported & Class3 & Domain location description (Hu et al., 2000). \\
\hline $\begin{array}{l}\text { BRCT } \\
\text { DOMAINS }\end{array}$ & 1650 & 1863 & $\begin{array}{l}\text { T1685A (c.5053A>G [p.Thr1685Ala]) } \\
\text { T1685I (c.5054C>T [p.Thr1685Ile]) } \\
\text { V1688del (c.5062_5064del } \\
\text { [p.Val1688del]) } \\
\text { R1699W (c.5095C>T [p.Arg1699Trp]) } \\
\text { G1706E (c.5117G>A [p.Gly1706Glu]) } \\
\text { A1708E (c.5123C>A [p.Ala1708Glu]) } \\
\text { S1715R (c.5143A>C [p.Ser1715Arg]) } \\
\text { G1738R (c.5212G>A [p.Gly1738Arg]) } \\
\text { L1764P (c.5291T>C [p.Leu1764Pro]) } \\
\text { I1766S (c.5297T>G [p.Ile1766Ser]) } \\
\text { M1775K (c.5324T>A [p.Met1775Lys]) } \\
\text { M1775R (c.5324T>G [p.Met1775Arg]) } \\
\text { C1787S (c.5359T>A [p.Cys1787Ser]) } \\
\text { G1788V (c.5363G>T [p.Gly1788Val]) } \\
\text { V1838E (c.5513T>A [p.Val1838Glu]) }\end{array}$ & $\begin{array}{l}\text { Class5 if at least } \\
\text { one clinically rel- } \\
\text { evant residue is } \\
\text { removed. Other- } \\
\text { wise Class3. }\end{array}$ & $\begin{array}{l}\text { Domain boundaries derived from X-ray crystallography } \\
\text { data are aa1646-1863 (1T15, http://www.ncbi.nlm.nih. } \\
\text { gov/Structure/mmdb/mmdbsrv.cgi?uid=27907), and } \\
\text { ENIGMA functional assay data (Monteiro, unpublished). } \\
\text { Digestion data indicate aa1860-1863 are dispensable } \\
\text { based on susceptibility to digestion (Lee et al., 2010), } \\
\text { while pathogenic variant data indicate that } 1855-1862 \\
\text { are dispensable (Hayes et al., 2000). Position } 1854 \text { is } \\
\text { implicated as clinically important by the observation } \\
\text { that Y1853X (c.5559C }>\mathrm{G} \text { [p.Tyr1853Ter]) is a recog- } \\
\text { nised high-risk pathogenic variant. } \\
\text { These combined data indicate that position } 1854 \text { or } \\
1855 \text { is the C-terminal border of the BRCT/BRCA1 rele- } \\
\text { vant for the clinical interpretation of sequence variants } \\
\text { in exon } 24 \text { of BRCA1. That is, a variant predicted to } \\
\text { disrupt expression of protein sequence only down- } \\
\text { stream* of position } 1855 \text { would not be considered } \\
\text { clinically important. }\end{array}$ \\
\hline
\end{tabular}

a Missense substitutions in specific functional domains that are designated as Class 5 pathogenic based on multifactorial likelihood of the posterior probability of pathogenicity > 0.99 (listed in http://hci-exlovd.hci.utah.edu or individual references), and which have no/little effect on the mRNA transcript profile, unless the variant results in an aberrant transcript that encodes a discrete in-frame deletion considered informative for the definition of clinically important domains.

* Typo was corrected in version 2.5.1.

Note: The following pathogenic exonic variants known to alter mRNA splicing have been excluded from Table 3 above, as justified below:

\begin{tabular}{|c|c|c|c|}
\hline Variant & mRNA Change & $\begin{array}{l}\text { Predicted } \\
\text { protein change }\end{array}$ & Reason for exclusion \\
\hline $\begin{array}{l}\text { BRCA1 R1495M } \\
\text { (c.4484G>T [p.Arg1495Met]) }\end{array}$ & r.[4358_4484del, 4358_4675del] & $\begin{array}{l}\text { p.(Ala1453Glyfs } \\
\text { Ter10) - } \\
\text { predominant } \\
\text { transcript }\end{array}$ & $\begin{array}{l}\text { Predominant alternate transcript is out of frame. Loss of } \\
\text { function is assumed due to loss of full-length transcript } \\
\text { from variant allele (Houdayer et al., 2012, Colombo et } \\
\text { al., 2013, Santos et al., 2014). }\end{array}$ \\
\hline $\begin{array}{l}\text { BRCA1 E1559K } \\
\text { (c.4675G>A [p.Glu1559Lys]) }\end{array}$ & r.[4665_4675del] & $\begin{array}{l}\text { p.(Gln1366Alafs } \\
\text { Ter13) }\end{array}$ & $\begin{array}{l}\text { Alternate transcript is out-of-frame. Level of full-length } \\
\text { transcript not assessed (Wappenschmidt et al., 2012). }\end{array}$ \\
\hline $\begin{array}{l}\text { BRCA1 A1623G } \\
\text { (c.4868C>G [p.Ala1623Gly]) }\end{array}$ & r.[4868_4986del] & $\begin{array}{l}\text { p.(Ala1623Aspfs } \\
\text { Ter16) }\end{array}$ & $\begin{array}{l}\text { Alternate transcript is out of frame. Variant allele pro- } \\
\text { duces some full-length transcripts (Walker et al., 2010). }\end{array}$ \\
\hline $\begin{array}{l}\text { BRCA1 D1692N } \\
\text { (c.5074G>A [p.Asp1692Asn]) }\end{array}$ & $\begin{array}{l}\text { r.[4987_5074del, 5074_5075ins5074 } \\
\left.+1 \_5074+153\right]\end{array}$ & $\begin{array}{l}\text { p.(Val1665Serfs } \\
\text { Ter8) - predomi- } \\
\text { nant transcript }\end{array}$ & $\begin{array}{l}\text { Predominant alternate transcript, based on minigene } \\
\text { assay (Ahlborn et al., 2015), is out of frame. }\end{array}$ \\
\hline
\end{tabular}


- Table 4 Excerpt from https://enigmaconsortium.org/wp-content/uploads/2018/10/ENIGMA_Rules_2017-06-29-v2.5.1.pdf.

Table 4: Catalogue of BRCA2 conserved domains/motifs and currently known clinically important amino acid residues, and relevance for classification of $B R C A 2$ in-frame and terminal exon sequence variants.

\begin{tabular}{|c|c|c|c|c|c|}
\hline $\begin{array}{l}\text { Do- } \\
\text { main/ } \\
\text { Motif }\end{array}$ & $\begin{array}{l}\text { AA } \\
\text { start }\end{array}$ & $\begin{array}{l}\text { AA } \\
\text { end }\end{array}$ & $\begin{array}{l}\text { AA alterations with demonstrated } \\
\text { clinical importance }^{\mathrm{a}}\end{array}$ & $\begin{array}{l}\text { Classification of } \\
\text { in-frame dele- } \\
\text { tions targeting } \\
\text { domain/motifs }\end{array}$ & References and summary interpretation ${ }^{a}$ \\
\hline $\begin{array}{l}\text { PALB2 } \\
\text { Binding }\end{array}$ & 10 & 40 & None reported & Class3 & $\begin{array}{l}\text { Domain location description (Oliver et al., 2009, } \\
\text { Xia et al., 2006) }\end{array}$ \\
\hline BRC-1 & 1002 & 1036 & None reported & Class3 & http://www.ncbi.nlm.nih.gov/protein/NP_000050.2 \\
\hline BRC-2 & 1212 & 1246 & None reported & Class3 & http://www.ncbi.nlm.nih.gov/protein/NP_000050.2 \\
\hline BRC-3 & 1422 & 1453 & None reported & Class3 & http://www.ncbi.nlm.nih.gov/protein/NP_000050.2 \\
\hline BRC-4 & 1518 & 1549 & None reported & Class3 & http://www.ncbi.nlm.nih.gov/protein/NP_000050.2 \\
\hline BRC-5 & 1665 & 1696 & None reported & Class3 & http://www.ncbi.nlm.nih.gov/protein/NP_000050.2 \\
\hline BRC-6 & 1837 & 1871 & None reported & Class3 & http://www.ncbi.nlm.nih.gov/protein/NP_000050.2 \\
\hline BRC-7 & 1971 & 2005 & None reported & Class3 & http://www.ncbi.nlm.nih.gov/protein/NP_000050.2 \\
\hline BRC-8 & 2051 & 2085 & None reported & Class3 & http://www.ncbi.nlm.nih.gov/protein/NP_000050.2 \\
\hline $\begin{array}{l}\text { DBD } \\
\text { (DNA/ } \\
\text { DSS1 } \\
\text { binding } \\
\text { domain } \\
\text { - helical, } \\
\text { OB1, } \\
\text { OB2, } \\
\text { OB3) }\end{array}$ & 2481 & 3186 & $\begin{array}{l}\text { W2626C (c.7878G>C [p.Trp2626Cys]) } \\
\text { I2627F (c.7879A>T [p.lle2627Phe]) } \\
\text { E2663V (c.7988A>T [p.Glu2663Val]) } \\
\text { T2722R (c.8165C>G [p.Thr2722Arg]) } \\
\text { D2723G (c.8168A>C [p.Asp2723Gly]) } \\
\text { D2723H (c.8167G>C [p.Asp2723His]) } \\
\text { G2748D (c.8243G>A [p.Gly2748Asp]) } \\
\text { I2778_Q2829del (c.8332_8487del } \\
\text { [p.lle2778_Gln2829del]) } \\
\text { R3052W (c.9154C>T [p.Arg3052Trp]) }\end{array}$ & $\begin{array}{l}\text { Class } 5 \text { if at least } \\
\text { one clinically } \\
\text { relevant residue } \\
\text { (or all of } \\
\text { AA2778-2829) } \\
\text { is removed. } \\
\text { Otherwise } \\
\text { Class3. }\end{array}$ & $\begin{array}{l}\text { http://www.ncbi.nlm.nih.gov/protein/NP_000050.2; http:// } \\
\text { hci-exlovd.hci.utah.edu. } \\
\text { Pathogenic variant c.8486G>A (also recorded as Gln2829Arg) } \\
\text { results in a transcript encoding an in-frame exon } 19 \text { deletion } \\
\text { only (Houdayer et al., 2012), indicating that genetic variation } \\
\text { encompassing loss of this entire exon (AA2778-2829) should } \\
\text { be considered clinically important. The clinical impact of } \\
\text { alteration/deletion of individual amino acids in exon } 19 \text { is not } \\
\text { yet established. }\end{array}$ \\
\hline NLS1 & 3263 & 3269 & None reported & Class3 & Domain local description (Guidugli et al., 2014) \\
\hline $\begin{array}{l}\text { BRC-9 or } \\
\text { TR2 }\end{array}$ & 3265 & 3330 & None reported & Class3 & $\begin{array}{l}\text { Note: although amino acids } 3270-3305 \text { within this fragment } \\
\text { are reported to bind RAD51-DNA filaments (Davies and Pelle- } \\
\text { grini, 2007), there is no sequence conservation with the BRC } \\
\text { repeats located between aa } 1002 \text { and aa2014. Domain } \\
\text { boundaries are derived from x-ray crystallography data are } \\
\text { aa3265-3330 (Esashi et al., 2005, Esashi et al., 2007). } \\
\text { Case-control and frequency data indicate that BRCA2 } \\
\text { c.9976A>T (p.Lys3326Ter) does not confer a high risk of cancer } \\
\text { (OR 1.3-1.5, dependent on breast or ovarian cancer subtype } \\
\text { (Meeks et al., 2016), demonstrating that residues at and } \\
\text { downstream of } 3327 \text { are likely dispensable. } \\
\text { Position } 3308 \text { is implicated as clinically important by the } \\
\text { observation that a nonsense variant c.9924C>G } \\
\text { (p.Tyr3308Ter) is recognized as a high-risk pathogenic variant } \\
\text { with known functional relevance ([Vallee et al., } 2016] ; \text { Bayes } \\
\text { score } 1122: 1 \text { from a single large } k \text { ConFab family, Spurdle un- } \\
\text { published data). There is currently no publicly available clinical } \\
\text { information to support pathogenicity of nonsense or frame- } \\
\text { shift variants located between positions } 3309 \text { and } 3325 \text {. } \\
\text { These data combined suggest that the C-terminal border of } \\
\text { the BRC-9 relevant to the clinical interpretation of sequence } \\
\text { variants in exon } 27 \text { of BRCA2 lies between } 3309 \text { and } 3325 \text {. That } \\
\text { is, a variant predicted to disrupt expression only of protein } \\
\text { sequence downstream of position } 3325 \text { would be considered } \\
\text { unlikely to be clinically important. Further functional and clin- } \\
\text { ical studies are underway to refine risk, if any, for predicted } \\
\text { nonsense or frameshift variants downstream of position } 3326 \text {. }\end{array}$ \\
\hline NLS2 & 3381 & 3385 & No & Class3 & $\begin{array}{l}\text { Domain location description (Guidugli et al., 2014). } \\
\text { This domain is considered unlikely clinically relevant since it } \\
\text { lies downstream of position } 3326 \text {. }\end{array}$ \\
\hline
\end{tabular}


\ Table 4 Excerpt from https://enigmaconsortium.org/wp-content/uploads/2018/10/ENIGMA_Rules_2017-06-29-v2.5.1.pdf. (Continued)

Missense substitutions in denoted functional domains that are designated as Class 5 pathogenic based on multifactorial likelihood posterior probability of pathogenicity $>0.99$, and for which there is no/little effect on mRNA transcript profile - unless the variant results in an aberrant transcript that encodes a discrete in-frame deletion considered informative to definition of clinically important domains. (Splicing aberrations are reported for BRCA2 c.7988A>T [p.Glu2663Val] and c.8168A>G [p.Asp2723Gly] (Walker et al., 2010), but these did not lead to complete loss of function of the full length transcript), and missense alterations showed abrogation of functional activity using multiple assays (Walker et al., 2010). An additional conserved region not commonly recognized as a BRCA2 domain/motif is located AA 1110-1183, but no pathogenic missense substitutions have been recorded for this region.

Note - The following pathogenic exonic variants known to alter mRNA splicing have been excluded from Table 4 above, as justified below:

\begin{tabular}{|c|c|c|c|}
\hline Variant & mRNA Change & $\begin{array}{l}\text { Predicted } \\
\text { protein change }\end{array}$ & Reason for exclusion \\
\hline $\begin{array}{l}\text { BRCA2 R2659K (c.7976G>A } \\
\text { [p.Arg2659Lys]) }\end{array}$ & r.[7806_7976del] & $\begin{array}{l}\text { p.(Ala2603_- } \\
\text { Arg2659del) }\end{array}$ & $\begin{array}{l}\text { Alternate transcript is in-frame but level of full length } \\
\text { transcript not assessed (Farrugia et al., 2008) }\end{array}$ \\
\hline $\begin{array}{l}\text { BRCA2 R2659T (c.7976G>C } \\
\text { [p.Arg2659Thr]) }\end{array}$ & r.[7806_7976del] & $\begin{array}{l}\text { p.(Ala2603_- } \\
\text { Arg2659del) }\end{array}$ & $\begin{array}{l}\text { Alternate transcript is in-frame but level of full length } \\
\text { transcript not assessed (Farrugia et al., 2008) }\end{array}$ \\
\hline $\begin{array}{l}\text { BRCA2 P3039P (c.9117G>A } \\
\text { [p.Pro3039Pro]) }\end{array}$ & r.[8954_9117del] & $\begin{array}{l}\text { p. }(\text { Val2985 } \\
\text { Glyfs*4) }\end{array}$ & $\begin{array}{l}\text { Allele-specific assay shows out-of-frame transcript } \\
\text { (Houdayer et al., 2012) }\end{array}$ \\
\hline
\end{tabular}

- Table 5 Excerpt from https://enigmaconsortium.org/wp-content/uploads/2018/10/ENIGMA_Rules_2017-06-29-v2.5.1.pdf.

Table 6: BRCA1 and BRCA2 exon boundary variants predicted or known to lead to naturally occurring in-frame RNA isoforms that may rescue gene functionality. Variants at these positions should be considered Class 3 Uncertain unless proven otherwise. ${ }^{*}$

\begin{tabular}{|c|c|c|c|}
\hline Gene & $\begin{array}{l}\text { Alternative } \\
\text { splicing event }\end{array}$ & Variants implicated & Rationale \\
\hline \multirow[t]{5}{*}{ BRCA1 } & $\Delta 8 p$ & $\begin{array}{l}\text { c.442-1 (IVS7-1) } \\
\text { c.442-2 (IVS7-2) }\end{array}$ & $\begin{array}{l}\text { BRCA1 exon } 8 \text { acceptor site is an experimentally validated tandem acceptor site (NAGNAG) } \\
\text { subject to alternative splicing (Colombo et al., 2014). c. } 442-1,-2 \text { variants are predicted to } \\
\text { inactivate the } 5^{\prime} \text { acceptor site, but not the } 3^{\prime} \text { acceptor site, thus producing } \triangle 8 \text { p transcripts. }\end{array}$ \\
\hline & $\Delta 9,10$ & $\begin{array}{l}\text { c. } 548-1 \text { (IVS8-1) } \\
\text { c. } 548-2 \text { (IVS8-2) } \\
\text { c. } 593 \text { to non-G } \\
\text { c. } 593+1 \text { (IVS9+1) } \\
\text { c. } 593+2 \text { (IVS9+2) } \\
\text { c.594-1 (IVS9-1) } \\
\text { c. } 594-2 \text { (IVS9-2) } \\
\text { c. } 670 \text { to non-G } \\
\text { c. } 670+1 \text { (IVS10+1) } \\
\text { c. } 670+2 \text { (IVS10+2) }\end{array}$ & $\begin{array}{l}\text { Carriers of variants at these positions are predicted to produce normal (or increased) levels } \\
\text { of } B R C A 1 \triangle(9,10) \text {, a major in-frame alternative splicing event (Colombo et al., 2014). } \\
\text { The } B R C A 1 \text { variant c.594-2A>C (shown from ENIGMA research to co-occur in cis with } \\
\text { c. } 641 A>G \text { ), has been reported to demonstrate clinical characteristics inconsistent with a high } \\
\text { risk of cancer expected for a pathogenic BRCA1 variant (Rosenthal et al., 2015). The haplotype } \\
\text { of c.[594-2A>C; } 641 A>G] \text { has been shown from mRNA analysis in human samples to produce } \\
\text { high levels of } \triangle 10 \text { transcripts ( } 70 \% \text { of the overall expression, and has been designated as } \\
\text { Class } 1 \text { Not Pathogenic by the ENIGMA Consortium using multifactorial likelihood analysis } \\
\text { that includes genetic (segregation, case-control analysis) and pathology data (de la Hoya et } \\
\text { al., 2016). }\end{array}$ \\
\hline & $\Delta 11 \mathrm{q}, \Delta 11$ & $\begin{array}{l}\text { c. } 4096 \text { to non-G } \\
\text { c. } 4096+1(\text { IVS } 11+1) \\
\text { c. } 4097+2(\text { IVS } 11+2)\end{array}$ & $\begin{array}{l}\text { Data collected by the ENIGMA consortium demonstrates that the } B R C A 1 \mathrm{c} .4096+1 \mathrm{G}>\mathrm{A} \\
\text { variant, proven to result in the production of naturally occurring in-frame transcripts } \triangle 11 \mathrm{q} \\
\text { (Bonatti et al., 2006) and also } \Delta 11 \text { (Radice, unpublished data), may not exhibit the clinical } \\
\text { characteristics of a standard high-risk pathogenic BRCA1 variant (Spurdle, unpublished data). }\end{array}$ \\
\hline & $\Delta 13 p$ & $\begin{array}{l}\text { c. } 4186-1 \text { (IVS12-1) } \\
\text { c. } 4186-2 \text { (IVS12-2) }\end{array}$ & $\begin{array}{l}\text { BRCA1 exon } 13 \text { acceptor site is an experimentally validated tandem acceptor site (NAGNAG) } \\
\text { subject to alternative splicing (Colombo et al., 2014). c. } 4186-1,-2 \text { variants are predicted to } \\
\text { inactivate the } 5^{\prime} \text { acceptor site, but not the } 3 \text { ' acceptor site, thus producing } \Delta 13 p \text { transcripts. }\end{array}$ \\
\hline & $\Delta 14 p$ & $\begin{array}{l}\text { c. } 4358-1 \text { (IVS13-1) } \\
\text { c. } 4358-2 \text { (IVS13-2) }\end{array}$ & $\begin{array}{l}\text { BRCA1 exon } 14 \text { acceptor site is an experimentally validated tandem acceptor site (NAGNAG) } \\
\text { subject to alternative splicing (Colombo et al., 2014). c. } 4358-1,-2 \text { variants are predicted to } \\
\text { inactivate the } 5^{\prime} \text { acceptor site, but not the } 3^{\prime} \text { acceptor site, thus producing } \Delta 14 \text { p transcripts. }\end{array}$ \\
\hline BRCA2 & $\Delta 12$ & $\begin{array}{l}\text { c. } 6842-1 \text { (IVS11-1) } \\
\text { c. } 6842-2 \text { (IVS11-2) } \\
\text { c. } 6937 \text { to non-G } \\
\text { c. } 6937+1 \text { (IVS12+1) } \\
\text { c. } 6937+2 \text { (IVS12+2) }\end{array}$ & $\begin{array}{l}\text { Carriers of these variants are predicted to produce exon } 12 \text { skipping. BRCA2 } \triangle 12 \text { is a naturally } \\
\text { occurring in-frame splicing event (Fackenthal et al., 2016). BRCA2 exon } 12 \text { is functionally } \\
\text { redundant (Li et al., 2009). }\end{array}$ \\
\hline
\end{tabular}

* This summary table does not yet capture the possibility of acceptor site changes leading to small in-frame deletions $>3$ bp, e.g. due to NAG (NNN) $n$ NAG sites. It is recommended that bioinformatic prediction analysis is carried out for variation in/near all donor and acceptor sites to assess the likelihood that a variant will or will not cause alternative splicing. 
> Table 5 Excerpt from https://enigmaconsortium.org/wp-content/uploads/2018/10/ENIGMA_Rules_2017-06-29-v2.5.1.pdf. (Continued)

Note: It could be argued that nonsense or frameshift variants in BRCA1 exon 9, BRCA1 exon 10, or BRCA2 exon 12 may not be associated with high risk of cancer due to rescue by the expression of in-frame naturally occurring isoforms that bypass the premature termination codon and thus encode a functional protein. A review of multiple clinical and control datasets for the frequency of unique nonsense or frameshift variants - adjusted for exon size - does not provide strong support for this hypothesis at present (Spurdle, de la Hoya, unpublished data). Additional research is underway to further investigate the functional/clinical importance of germline nonsense or frameshift variants in these exons.

Moreover, further work is planned within ENIGMA (led by Paolo Radice) to document variants that have undergone splicing assays and are proven to be "leaky" variants, to provide a record of all spliceogenic variants for which additional research is necessary. This resource will identify variants that have already been classified using clinical data, as positive and negative controls for future quantitative mRNA studies.

\section{A 5.2 ATM}

The evaluation criteria for ATM are based on a combination of the following criteria:

- The 5-class IARC system for the assessment of the pathogenicity of BRCA1 and BRCA2 variants.

- The 3-class system to evaluate the pathogenicity of ATM variants [20] which includes in silico analyses such as Align-GVGD.

- The ACMG guidelines on the classification of variants $[3,21]$.

- Additional literature: [22-28].

Class1:

- If the allele frequency is $\geq 1 \%$ (MAF $\geq 0.01$ ) in large population groups (e.g. Caucasians, Africans, or Asians) or there is evidence of homozygous variant carriers in control populations. If this is the case, then the variant is always categorised as Class 1 . An allele frequency of $\geq 1 \%$ in subpopulations with a low-diversity gene pool (examples: Finnish population, founder mutations!) is not sufficient.

\section{Class2:}

- If the allele frequency is $\geq 0.5-<1 \%$ (MAF $\geq 0.005-0.099$ ) in large population groups (e.g. Caucasians, Africans, or Asians), the variant is always categorised as Class2.

- Missense variants which, according to in silico analysis (AlignGVGD, SIFT), are very probably neutral and/or outside the functionally critical domain (FATKIN).
Class3:

- All variants which cannot be categorised as Class1, 2, 4 or 5.

Class4:

- Variants with an in-frame deletion which are within the functionally critical domain (FATKIN).

- Missense variants which are within the functionally critical domain (FATKIN) and are, according to in silico analysis (AlignGVGD, SIFT), very probably harmful and described as functionally inactive.

Class5:

- Truncating ATM variants up to the FATKIN domain.

- Missense variants, in-frame deletion or splice mutations which reduce ATM protein expression to $<20 \%$ for the mutated allele $[28,29]$.

- Variants associated with classic AT.

Splice variants: see BRCA1 and BRCA2.

Functional domains: FATKIN with FAT; PI3K-related kinase; FATC

- Table 6.

Additional literature: [22-26, 28, 33, 35, 38].

- Table 6 ATM, functional domains and relevance for the interpretation of the clinical importance of sequence variants - catalogue of clinically relevant functional domains and amino acids.

\begin{tabular}{|c|c|c|c|c|}
\hline Region & $\begin{array}{l}\text { AA } \\
\text { start }\end{array}$ & $\begin{array}{l}\text { AA } \\
\text { end }\end{array}$ & $\begin{array}{l}\text { AA alterations with demonstrated } \\
\text { clinical importance (AT) character- } \\
\text { ising known functional domains }\end{array}$ & References and summary interpretation \\
\hline $\begin{array}{l}\text { Substrate } \\
\text { binding }\end{array}$ & 91 & 97 & None reported & $\begin{array}{l}\text { Domain location description [30] } \\
\text { Also contains p53- and BRCA1-binding domain }\end{array}$ \\
\hline NLS & 385 & 388 & None reported & Domain location description $[28,31]$ \\
\hline Leucine zipper & 1218 & 1238 & None reported & Domain location description $[25,28]$ \\
\hline Proline rich & 1373 & 1382 & None reported & Domain location description $[25,28]$ \\
\hline FATKIN & 1893 & 3056 & $\begin{array}{l}\text { Yes, e.g. } \\
\text { p.(Val2424Gly) } \\
\text { p.(2546_2548del), in frame } \\
\text { p.(Asp2625Glu) } \\
\text { p.(Ala2626Pro) } \\
\text { p.(Val2716Ala) } \\
\text { p.(Ser2855_Val2856delinsArglle) }\end{array}$ & $\begin{array}{l}\text { AA alterations and in-frame deletions }[26,28,29,32-35] \\
\text { Domain location description }[25,27,28,36,37] \\
\text { Domains: } \\
\text { FAT: } 1893-2612 \\
\text { KIN: } 2612-3056 \text { with ATP-binding: } 2716-2730 \text {, substrate (nibrin and p53) } \\
\text { binding: } 2682-3012 \text {, FATC with TIP60 binding: } 3034-3056 \\
\text { Domain location description }\end{array}$ \\
\hline
\end{tabular}




\section{A 5.3 PALB2}

- The p.(Leu939Trp) mutation should be categorised as Class2

[39].

Additional literature: [35, 38, 40-46].

- Table 7.

- Table 7 PALB2, functional domains and relevance for the interpretation of the clinical importance of sequence variants - catalogue of clinically relevant functional domains and amino acids.

\begin{tabular}{|l|l|l|l|l|}
\hline Region & $\begin{array}{l}\text { AA } \\
\text { start }\end{array}$ & $\begin{array}{l}\text { AA } \\
\text { end }\end{array}$ & $\begin{array}{l}\text { AA alterations with potential } \\
\text { clinical importance }\end{array}$ & References and summary interpretation \\
\hline $\begin{array}{l}\text { BRCA1 interaction } \\
\text { domain }\end{array}$ & 9 & 43 & $\begin{array}{l}\text { Yes, e.g. } \\
\text { p.(Leu35Pro) }\end{array}$ & $\begin{array}{l}\text { Also covers oligomerisation domain/covers coiled-coiled motif } \\
\text { Domain location description [47-49]; } \\
\text { Amino acid alteration in VUS and functional analysis [50]. }\end{array}$ \\
\hline DNA-binding site & 1 & 200 & None reported & Domain location description [51] \\
\hline RAD51 binding site & 101 & 184 & None reported & Domain location description [51,52] \\
\hline DNA-binding site & 372 & 561 & None reported & $\begin{array}{l}\text { Covers also chromatin association motif (ChAM, 395-446) } \\
\text { Domain location description [51,53] }\end{array}$ \\
\hline $\begin{array}{l}\text { MRG15 (MORF4L1) } \\
\text { interaction domain }\end{array}$ & 611 & 764 & None reported & Domain location description [48] \\
\hline WD40 repeat & 853 & 1186 & $\begin{array}{l}\text { Yes, e.g. } \\
\text { p.(Thr1030lle) } \\
\text { p.(Leu1143Pro) }\end{array}$ & $\begin{array}{l}\text { BRCA2 (1019-1098), RAD51C, XRCC3 and/or RAD51 complex formation } \\
\text { Domain location description [51,52, 54-57]. } \\
\text { Amino acid alterations [48, 54, 58] }\end{array}$ \\
\hline & & & &
\end{tabular}

\section{A 5.4 CHEK2}

In exons 11-15, highly homologous, functionally inactive sequences (pseudogenes) on various other chromosomes $(2,7,10$, $13,15,16, X$, and $Y)[59,60]$ which can superimpose the relevant sequences $>$ long-range PCR of exons 11-15 and bioinformatic filtering of pseudogene reads, where possible.

Functional domains: SQ/TQ-rich domain*, forkhead-associated $(\mathrm{FHA})^{* *}$ domain, kinase domain***, nuclear localisation signal (NLS) [61-63].

- To date, only truncating variants in the SQ/TQ-rich domain have been classified as pathogenic ( $>$ Table 8 ).

- Numerous known missense variants in the FHA domain. Caution: Consult FLOSSIES database during evaluation! (e.g. c.470C>T; p.lle157Thr: Class2 [see § footnote $>$ Table 8]) or with unclear clinical relevance (e.g. c.434G>A, p.Arg145Gln; c.422A>C, p.Lys141Thr).

- Missense variants in the kinase domain with unclear clinical relevance: e.g. c.1216C>T, p.Arg406Cys.

- Similarly, in the NLS domain, only truncating variants have been classified as pathogenic to date ( $\bullet$ Table 8 ).
The investigation by Ow et al. [63] gives an overview of the identified mutations in the CHEK2 gene region. The publication by Roeb et al. (2012) includes a schematic overview of the functional domains as well as the results of functional analyses of the missense mutations located in these different CHEK2 domains [62].

\section{A 5.5 TP53}

- IARC TP53 database; the functional analyses by Kato et al. (2003) and Monti et al. $(2007,2011)$ are reliable [72 - 77].

- Functional domains: oligomerisation domain, core domain (DNA-binding).

- Possible dominant negative effect of missense variants and stop variants which affect the oligomerisation domain.

- Mosaic mutations and clonal haematopoiesis are possible, therefore watch out for the variant allele fraction when carrying out NGS analysis; if necessary, carry out further analysis to confirm germline mutations.

\section{- Table 9.}


- Table 8 CHEK2, functional domains and relevance for the interpretation of the clinical importance of sequence variants - catalogue of clinically relevant functional domains and amino acids.

\begin{tabular}{|c|c|c|c|c|}
\hline Region & AA start & $A A$ end & AA alterations with Potential Clinical Importance & $\begin{array}{l}\text { References and summary } \\
\text { interpretation }\end{array}$ \\
\hline SQ/TQ-rich & 19 & 69 & e.g. c. $85 C>T, p . G \ln 29^{*}$ & {$[62,65]$} \\
\hline FHA & $92[115]$ & 205 [175] & p.Arg117Gly, p.Arg145Trp, p.Gly167Arg & [61-63] \\
\hline Kinase & 212 & 501 & $\begin{array}{l}\text { c.1040A>C, p.Asp347Ala \#; c.1100del; c. } 1164 \text { dup; p. Thr476Met, } \\
\text { c.1169A>C, p.Tyr390Ser; c.1183G>T, p.Val395Phe\#; c.1283C>T, } \\
\text { p.Ser428Phe; c.1427C>T, p.Thr476Met }\end{array}$ & {$[61,62], \#$ ClinVar } \\
\hline NLS & 515 & 538 & e.g. c.1547delC, p.Ser516Leufs\#; c.1555C>T, p.Arg519Ter\#; & [63], \#ClinVar \\
\hline \multicolumn{5}{|c|}{$\begin{array}{ll}* * & \text { The phos } \\
& {[66] .} \\
* * * & {[67]}\end{array}$} \\
\hline$\S \quad$ The $C r$ & $\begin{array}{l}\text { c. } 470 T>C P \\
\text { has been re } \\
\text { ntly listed ir } \\
\text { ygous carri } \\
\text { ed }>70 \text { yea } \\
\text { w results ir } \\
\text { ditionally, }\end{array}$ & $\begin{array}{l}\text { 157Thr va } \\
\text { ssified (dat } \\
\text { rge unaffec } \\
\text { ). In additio } \\
\text { Although } \\
\text { ating low c } \\
\text { as been ob }\end{array}$ & $\begin{array}{l}\text { gh still present with various classifications (VUS/likely pathogenic/p } \\
\text { 8) as Class } 2 / \text { likely benign by the German Consortium on HBOC on t } \\
\text { cohorts ( } 0.5 \% \text {, gnomAD V. } 2.1 .1 \text {, non-cancer). The population frequ } \\
\text { nt in } 47 / 7325 \text { individuals }(0.64 \% \text { ) in the FLOSSIES database (non-car } \\
\text { ctionally impaired dimerisation and autophosphorylation [ } 61,62,68 \\
\text { ed breast cancer risk [ } 64,69] \text { : breast cancer OR }=1.58(1.42-1.75) \text {, } \\
\text { a frequency of } 2 \% \text { in controls [ } 2] \text {. However, it may act as a polygenic }\end{array}$ & $\begin{array}{l}\text { ogenic) in ClinVar and other } \\
\text { ollowing basis: } \\
\text { cy in Finnish Europeans is } 2.5 \% \\
\text { female controls of European } \\
\text { umerous large case-control } \\
\text { on cancer OR = } 1.67 \text { (1.24-2.26) } \\
\text { < allele. }\end{array}$ \\
\hline
\end{tabular}

- Table 9 p53, functional domains and relevance for the interpretation of the clinical importance of sequence variants - catalogue of clinically relevant functional domains and amino acids.

\begin{tabular}{|c|c|c|c|c|}
\hline Region & $\begin{array}{l}\text { AA } \\
\text { start }\end{array}$ & $\begin{array}{l}A A \\
\text { end }\end{array}$ & $\begin{array}{l}\text { AA alterations } \\
\text { with demonstrat- } \\
\text { ed clinical impor- } \\
\text { tance (including } \\
\text { conflicting inter- } \\
\text { pretations of } \\
\text { pathogenicity but } \\
\text { criteria provided) }\end{array}$ & $\begin{array}{l}\text { References } \\
\text { and summary } \\
\text { interpretation }\end{array}$ \\
\hline $\begin{array}{l}\text { Tran- } \\
\text { scription } \\
\text { activa- } \\
\text { tion }\end{array}$ & 1 & 55 & $\begin{array}{l}\text { p.(Val10lle) } \\
\text { p.(Val31lle) } \\
\text { p.(Pro47Ser) }\end{array}$ & $\begin{array}{l}\text { Amino acid altera- } \\
\text { tions (ClinVar) } \\
\text { Domain location } \\
\text { description [78] } \\
\text { Also binding site } \\
\text { for numerous } \\
\text { proteins including } \\
\text { HDM2 (amino } \\
\text { acids 15-29; IARC) }\end{array}$ \\
\hline $\begin{array}{l}\text { Proline- } \\
\text { rich } \\
\text { domain }\end{array}$ & 61 & 94 & $\begin{array}{l}\text { p.(Pro82Leu) } \\
\text { p.(Ala83Val) }\end{array}$ & $\begin{array}{l}\text { Amino acid altera- } \\
\text { tions (ClinVar) } \\
\text { Domain location } \\
\text { description [78] }\end{array}$ \\
\hline
\end{tabular}

- Table 9 p53, functional domains and relevance for the interpretation of the clinical importance of sequence variants - catalogue of clinically relevant functional domains and amino acids. (Continued)

\begin{tabular}{|c|c|c|c|c|}
\hline Region & $\begin{array}{l}\text { AA } \\
\text { start }\end{array}$ & $\begin{array}{l}\text { AA } \\
\text { end }\end{array}$ & $\begin{array}{l}\text { AA alterations } \\
\text { with demonstrat- } \\
\text { ed clinical impor- } \\
\text { tance (including } \\
\text { conflicting inter- } \\
\text { pretations of } \\
\text { pathogenicity but } \\
\text { criteria provided) }\end{array}$ & $\begin{array}{l}\text { References } \\
\text { and summary } \\
\text { interpretation }\end{array}$ \\
\hline $\begin{array}{l}\text { DNA- } \\
\text { binding } \\
\text { region }\end{array}$ & 102 & 292 & $\begin{array}{l}\text { p.(Gly105Asp) } \\
\text { p.(Lys120Glu) } \\
\text { p.(Thr125Met) } \\
\text { p.(Ser127Phe) } \\
\text { p.(Asn131Tyr) } \\
\text { p.(Cys141Tyr) } \\
\text { p.(Pro151Ser) } \\
\text { p.(Pro151Thr) } \\
\text { p.(Pro152Leu) } \\
\text { p.(Arg156His) } \\
\text { p.(Arg158Cys) } \\
\text { p.(Arg158His) } \\
\text { p.(Tyr163Asp) } \\
\text { p.(Tyr163Cys) } \\
\text { p.(Arg175Leu) } \\
\text { p.(Arg175His) }\end{array}$ & $\begin{array}{l}\text { Amino acid altera- } \\
\text { tions (ClinVar) } \\
\text { Domain location } \\
\text { description (IARC) } \\
\text { Also binding site } \\
\text { for numerous pro- } \\
\text { teins including } \\
53 B P 1 \text { (IARC) and } \\
\text { RAD51 amino acids } \\
94-160 \text { and 264- } \\
315 \text { [79] }\end{array}$ \\
\hline
\end{tabular}


- Table 9 p53, functional domains and relevance for the interpretation of the clinical importance of sequence variants - catalogue of clinically relevant functional domains and amino acids. (Continued)

\begin{tabular}{|c|c|c|c|c|}
\hline Region & $\begin{array}{l}\text { AA } \\
\text { start }\end{array}$ & $\begin{array}{l}A A \\
\text { end }\end{array}$ & $\begin{array}{l}\text { AA alterations } \\
\text { with demonstrat- } \\
\text { ed clinical impor- } \\
\text { tance (including } \\
\text { conflicting inter- } \\
\text { pretations of } \\
\text { pathogenicity but } \\
\text { criteria provided) }\end{array}$ & $\begin{array}{l}\text { References } \\
\text { and summary } \\
\text { interpretation }\end{array}$ \\
\hline & & & $\begin{array}{l}\text { p.(Cys176Tyr) } \\
\text { p.(His179Tyr) } \\
\text { p.(Arg181Cys) } \\
\text { p.(Arg181His) } \\
\text { p.(Ala189Val) } \\
\text { p.(His193Arg) } \\
\text { p.(His193Leu) } \\
\text { p.(Leu194Phe) } \\
\text { p.(Ile195Thr) } \\
\text { p.(Arg213Gln) } \\
\text { p.(Val.216Met) } \\
\text { p.(Tyr220Cys) } \\
\text { p.(Tyr220Ser) } \\
\text { p.(Ile232Thr) } \\
\text { p.(Tyr234Cys) } \\
\text { p.(Asn235Ser) } \\
\text { p.(Tyr236Asp) } \\
\text { p.(Met237Val) } \\
\text { p.(Met237lle) } \\
\text { p.(Cys238Tyr) } \\
\text { p.(Ser241Phe) } \\
\text { p.(Cys242Tyr) } \\
\text { p.(Gly245Asp) } \\
\text { p.(Gly245Ser) } \\
\text { p.(Gly245Cys) } \\
\text { p.(Met246Val) } \\
\text { p.(Met246Leu) } \\
\text { p.(Met246Arg) } \\
\text { p.(Arg248Gln) } \\
\text { p.(Arg248Trp) } \\
\text { p.(Ile251Leu) } \\
\text { p.(Ile251Ser) } \\
\text { p.(Thr256Ala) } \\
\text { p.(Leu257Arg) }\end{array}$ & \\
\hline
\end{tabular}

- Table 9 p53, functional domains and relevance for the interpretation of the clinical importance of sequence variants - catalogue of clinically relevant functional domains and amino acids. (Continued)

\begin{tabular}{|c|c|c|c|c|}
\hline \multirow[t]{2}{*}{ Region } & $\begin{array}{l}\text { AA } \\
\text { start }\end{array}$ & $\begin{array}{l}A A \\
\text { end }\end{array}$ & $\begin{array}{l}\text { AA alterations } \\
\text { with demonstrat- } \\
\text { ed clinical impor- } \\
\text { tance (including } \\
\text { conflicting inter- } \\
\text { pretations of } \\
\text { pathogenicity but } \\
\text { criteria provided) }\end{array}$ & $\begin{array}{l}\text { References } \\
\text { and summary } \\
\text { interpretation }\end{array}$ \\
\hline & & & $\begin{array}{l}\text { p.(Glu258Lys) } \\
\text { p.(Arg267Trp) } \\
\text { p.(Arg267Gln) } \\
\text { p.(Val272Leu) } \\
\text { p.(Arg273Hisv } \\
\text { p.(Arg273Cys) } \\
\text { p.(Cys275Tyr) } \\
\text { p.(Cys277Tyr) } \\
\text { p.(Arg280Thr) } \\
\text { p.(Asp281Val) } \\
\text { p.(Asp281Gly) } \\
\text { p.(Arg282Gly) } \\
\text { p.(Arg282Leu) } \\
\text { p.(Arg282Trp) } \\
\text { p.(Arg283His) } \\
\text { p.(Arg283Lys) } \\
\text { p.(Glu286Lys) }\end{array}$ & \\
\hline $\begin{array}{l}\text { Oligo- } \\
\text { merisa- } \\
\text { tion } \\
\text { region }\end{array}$ & 325 & 356 & $\begin{array}{l}\text { p.(Gly325Val) } \\
\text { p.(Arg337Leu) } \\
\text { p.(Arg337Cys) } \\
\text { p.(Glu339Lys) } \\
\text { p.(Arg342Pro) }\end{array}$ & $\begin{array}{l}\text { Amino acid altera- } \\
\text { tions (ClinVar) } \\
\text { Domain location } \\
\text { description (IARC) } \\
\text { Also binding site } \\
\text { for numerous pro- } \\
\text { teins } \\
\text { Covering main } \\
\text { nuclear localisation } \\
\text { signal (amino acids } \\
316-322 \text { ) }[80,81]\end{array}$ \\
\hline $\begin{array}{l}\text { Basic } \\
\text { (repres- } \\
\text { sion of } \\
\text { DNA- } \\
\text { binding } \\
\text { region) }\end{array}$ & 369 & 388 & None reported & $\begin{array}{l}\text { Domain location } \\
\text { description (IARC) } \\
\text { Also binding site } \\
\text { for numerous pro- } \\
\text { teins including } \\
\text { RAD54 [82] }\end{array}$ \\
\hline
\end{tabular}

\section{A 5.6 RAD51D}

Functional domains: N-terminal domains and ATP-binding domain with the highly conserved Walker A and B motifs [83-85].

> Table 10.

Additional literature: [91-94]

\section{A 5.7 RAD51C}

References: [91,95-101]

Functional domains: DNA repair/recombination protein RecA-like, ATP-binding domain

• Table 11.

\section{A 5.8 BRIP1}

$\checkmark$ Table 12.

Additional literature: [1, 102, 105-110] 
- Table $10 R A D 51 D$, functional domains and relevance for the interpretation of the clinical importance of sequence variants - catalogue of clinically relevant functional domains and amino acids.

\begin{tabular}{|l|c|c|l|l|}
\hline Region & $\begin{array}{l}\text { AA } \\
\text { start }\end{array}$ & $\begin{array}{l}\text { AA } \\
\text { end }\end{array}$ & $\begin{array}{l}\text { AA alterations with demonstrated clinical importance } \\
\text { (including conflicting interpretations of pathogenicity) }\end{array}$ & References and summary interpretation \\
\hline $\begin{array}{l}\text { N-terminal } \\
\text { region }\end{array}$ & 1 & 83 & None reported & $\begin{array}{l}\text { N-terminal domain required for ssDNA-specific } \\
\text { binding function [86] }\end{array}$ \\
\hline Linker & 60 & 78 & None reported & Proper interaction with RAD51C and XRCC2 [85] \\
\hline $\begin{array}{l}\text { ATPase domain } \\
\text { and RAD51B, } \\
\text { RAD51C, and } \\
\text { XRCC2 binding }\end{array}$ & 99 & 274 & $\begin{array}{l}\text { p.(G112A) (disrupts binding of RAD51D to RAD51C [87]) } \\
\text { p.(S207L) (disrupts RAD51D-XRCC2 interaction [85]) }\end{array}$ & $\begin{array}{l}\text { ATPase, AAA+ type } \\
\text { Walker A and B motifs crucial for HR. These motifs are } \\
\text { a.(A210V) (predicted to be potentially pathogenic [88, 89]) } \\
\text { a.(R266C) [90], Meindl et al. (unpublished) }\end{array}$ \\
\hline
\end{tabular}

- Table 11 RAD51C, functional domains and relevance for the interpretation of the clinical importance of sequence variants - catalogue of clinically relevant functional domains and amino acids.

\begin{tabular}{|l|c|c|l|l|}
\hline Region & $\begin{array}{l}\text { AA } \\
\text { start }\end{array}$ & $\begin{array}{l}\text { AA } \\
\text { end }\end{array}$ & $\begin{array}{l}\text { AA alterations with demonstrated clinical importance } \\
\text { (including conflicting interpretations of pathogenicity) }\end{array}$ & References and summary interpretation \\
\hline $\begin{array}{l}\text { N-terminal } \\
\text { region }\end{array}$ & 1 & 66 & None reported & $\begin{array}{l}\text { Homology-derived putative DNA-binding domain } \\
{[91]}\end{array}$ \\
\hline $\begin{array}{l}\text { ATPase domain } \\
\text { and RAD51B, } \\
\text { XRCC3, and } \\
\text { RAD51D } \\
\text { binding }\end{array}$ & 79 & 376 & $\begin{array}{l}\text { p.(Gly125Val) } \\
\text { p.(Cys135Tyr) } \\
\text { p.(Leu138Phe) } \\
\text { p.(Gly153Asp) } \\
\text { p.(Asp159Asn) } \\
\text { p.(Val169Ala) } \\
\text { p.(Leu219Ser) } \\
\text { p.(Arg258His) } \\
\text { p.(Gly264Ser) }\end{array}$ & $\begin{array}{l}\text { Amino acid alterations and functional consequences } \\
\text { [95-98] Domain location description [91] ATPase } \\
\text { domain includes Walker A nucleotide binding motif } \\
\text { (amino acids 125-132) and Walker B nucleotide }\end{array}$ \\
binding motif (amino acids 238-242) [91, 99]
\end{tabular}

Table 12 BRIP1, functional domains and relevance for the interpretation of the clinical importance of sequence variants - catalogue of clinically relevant functional domains and amino acids.

\begin{tabular}{|l|c|c|c|c|}
\hline Region & $\begin{array}{l}\text { AA } \\
\text { start }\end{array}$ & $\begin{array}{l}\text { AA } \\
\text { end }\end{array}$ & $\begin{array}{l}\text { AA alterations with demonstrated clinical importance } \\
\text { (including conflicting interpretations of pathogenicity) }\end{array}$ & References and summary interpretation \\
\hline $\begin{array}{l}\text { DEAD/DEAH box } \\
\text { helicase domain }\end{array}$ & 17 & 441 & & Domain location description [102] \\
\hline $\begin{array}{l}\text { Helicase superfamily } \\
\text { c-terminal domain }\end{array}$ & 697 & 851 & & Domain location description [102] \\
\hline $\begin{array}{l}\text { The BRCA1 interact- } \\
\text { ing region of BRIP1 }\end{array}$ & 976 & 1006 & $\begin{array}{l}\text { Phosphorylation of FANC] at Ser-990 is important for its } \\
\text { interaction with BRCA1 }\end{array}$ & [103] \\
\hline $\begin{array}{l}\text { MLH1 interaction } \\
\text { Luclear localisation }\end{array}$ & 158 & 175 & $\begin{array}{l}\text { Lysines 141 and 142 are required for direct interaction } \\
\text { of FANC) with MLH1 }\end{array}$ & [104] \\
\hline $\begin{array}{l}\text { None reported } \\
\text { signal }\end{array}$ & & & Domain location description [102] \\
\hline
\end{tabular}




\section{A $5.9 \mathrm{CDH} 1$}

References:

Focuses predominantly on molecular genetics: [111]

Review of functional analyses: [112]

Review of the HDGC Consortium: [113]

Review of lobular breast cancer: [114]

Distribution of pathogenic variants at the $C D H 1$ locus [111]

Known pathogenic $\mathrm{CDH} 1$ variants are distributed across the entire locus; it is therefore not possible to define a clinically relevant functional protein domain. The last known truncating pathogenic variant in the last exon is c.2506G>T (p.Glu836*) [115]. All truncating variants upstream must therefore be categorised at least as Class4.

The proposal put forwards by the ClinGen Consortium to categorise variants with a MAF $>0.2 \%$ as ACMG Class1, contrary to IARC guidelines, is currently being debated.

CDH1 Rule Specifications for the ACMG/AMP Variant Curation Guidelines ClinGen (https://www.clinicalgenome.org/site/assets/ files/8816/clingen_cdh1_acmg_specifications_v1.pdf).

\section{Conflict of Interest}

The authors declare that they have no conflict of interest.

\section{References}

[1] Couch FJ, Shimelis H, Hu C et al. Associations Between Cancer Predisposition Testing Panel Genes and Breast Cancer. JAMA Oncol 2017; 3: 1190-1196. doi:10.1001/jamaoncol.2017.0424

[2] Hauke J, Horvath J, Gross E et al. Gene panel testing of 5589 BRCA1/2negative index patients with breast cancer in a routine diagnostic setting: results of the German Consortium for Hereditary Breast and Ovarian Cancer. Cancer Med 2018; 7: 1349-1358. doi:10.1002/cam4.1376

[3] Richards S, Aziz N, Bale S et al. Standards and guidelines for the interpretation of sequence variants: a joint consensus recommendation of the American College of Medical Genetics and Genomics and the Association for Molecular Pathology. Genet Med 2015; 17: 405-424. doi:10.1038/gim.2015.30

[4] Plon SE, Eccles DM, Easton D et al. Sequence variant classification and reporting: recommendations for improving the interpretation of cancer susceptibility genetic test results. Hum Mutat 2008; 29: 1282-1291. doi:10.1002/humu.20880

[5] Moghadasi S, Meeks HD, Vreeswijk MP et al. The BRCA1 c. 5096G>A p. Arg1699GIn (R1699Q) intermediate risk variant: breast and ovarian cancer risk estimation and recommendations for clinical management from the ENIGMA consortium. J Med Genet 2018; 55: 15-20. doi:10.1136/ jmedgenet-2017-104560

[6] Shimelis H, Mesman RLS, Von Nicolai C et al. BRCA2 Hypomorphic Missense Variants Confer Moderate Risks of Breast Cancer. Cancer Res 2017; 77: 2789-2799. doi:10.1158/0008-5472.can-16-2568

[7] Walker LC, Whiley PJ, Houdayer C et al. Evaluation of a 5-tier scheme proposed for classification of sequence variants using bioinformatic and splicing assay data: inter-reviewer variability and promotion of minimum reporting guidelines. Hum Mutat 2013; 34: 1424-1431. doi:10.1002/ humu.22388

[8] Whiley PJ, de la Hoya M, Thomassen M et al. Comparison of mRNA splicing assay protocols across multiple laboratories: recommendations for best practice in standardized clinical testing. Clin Chem 2014; 60: 341352. doi:10.1373/clinchem.2013.210658
[9] Fackenthal JD, Yoshimatsu T, Zhang B et al. Naturally occurring BRCA2 alternative mRNA splicing events in clinically relevant samples. J Med Genet 2016; 53: 548-558. doi:10.1136/jmedgenet-2015-103570

[10] Colombo M, Blok M], Whiley P et al. Comprehensive annotation of splice junctions supports pervasive alternative splicing at the BRCA1 locus: a report from the ENIGMA consortium. Hum Mol Genet 2014; 23: 36663680. doi: $10.1093 / \mathrm{hmg} / \mathrm{ddu} 075$

[11] de la Hoya M, Soukarieh O, Lopez-Perolio I et al. Combined genetic and splicing analysis of BRCA1 c.[594-2A>C; 641A>G] highlights the relevance of naturally occurring in-frame transcripts for developing disease gene variant classification algorithms. Hum Mol Genet 2016; 25: 22562268. doi:10.1093/hmg/ddw094

[12] Li L, Biswas K, Habib LA et al. Functional redundancy of exon 12 of BRCA2 revealed by a comprehensive analysis of the c.6853A>G (p. $12285 \mathrm{~V}$ ) variant. Hum Mutat 2009; 30: 1543-1550. doi:10.1002/humu.21101

[13] Goldgar DE, Easton DF, Deffenbaugh AM et al. Integrated evaluation of DNA sequence variants of unknown clinical significance: application to BRCA1 and BRCA2. Am J Hum Genet 2004; 75: 535-544. doi:10.1086/ 424388

[14] Houdayer C, Caux-Moncoutier V, Krieger S et al. Guidelines for splicing analysis in molecular diagnosis derived from a set of 327 combined in silico/in vitro studies on BRCA1 and BRCA2 variants. Hum Mutat 2012; 33: 1228-1238. doi:10.1002/humu.22101

[15] Findlay GM, Boyle EA, Hause RJ et al. Saturation editing of genomic regions by multiplex homology-directed repair. Nature 2014; 513: 120 123. doi:10.1038/nature13695

[16] Starita LM, Young DL, Islam M et al. Massively Parallel Functional Analysis of BRCA1 RING Domain Variants. Genetics 2015; 200: 413-422. doi:10.1534/genetics.115.175802

[17] Meeks HD, Song H, Michailidou K et al. BRCA2 Polymorphic Stop Codon K3326X and the Risk of Breast, Prostate, and Ovarian Cancers. J Natl Cancer Inst 2016; 108: pii: djv315. doi:10.1093/jnci/djv315

[18] Hayes F, Cayanan C, Barilla D et al. Functional assay for BRCA1: mutagenesis of the $\mathrm{COOH}$-terminal region reveals critical residues for transcription activation. Cancer Res 2000; 60: 2411-2418

[19] Kuznetsov SG, Liu P, Sharan SK. Mouse embryonic stem cell-based functional assay to evaluate mutations in BRCA2. Nat Med 2008; 14: 875881. doi: $10.1038 / \mathrm{nm} .1719$

[20] Goldgar DE, Healey S, Dowty JG et al. Rare variants in the ATM gene and risk of breast cancer. Breast Cancer Res 2011; 13: R73. doi:10.1186/ bcr2919

[21] Maxwell KN, Hart SN, Vijai J et al. Evaluation of ACMG-Guideline-Based Variant Classification of Cancer Susceptibility and Non-Cancer-Associated Genes in Families Affected by Breast Cancer. Am J Hum Genet 2016; 98: 801-817. doi:10.1016/j.ajhg.2016.02.024

[22] Teraoka SN, Malone KE, Doody DR et al. Increased frequency of ATM mutations in breast carcinoma patients with early onset disease and positive family history. Cancer 2001; 92: 479-487

[23] Fernet M, Moullan N, Lauge A et al. Cellular responses to ionising radiation of AT heterozygotes: differences between missense and truncating mutation carriers. Br J Cancer 2004; 90: 866-873. doi:10.1038/sj.bjc. 6601549

[24] Dörk T, Bendix-Waltes R, Wegner RD et al. Slow progression of ataxiatelangiectasia with double missense and in frame splice mutations. Am J Med Genet A 2004; 126A: 272-277. doi:10.1002/ajmg.a.20601

[25] Lavin MF, Scott $S$, Gueven $N$ et al. Functional consequences of sequence alterations in the ATM gene. DNA Repair (Amst) 2004; 3: 1197-1205. doi:10.1016/j.dnarep.2004.03.011

[26] Renwick A, Thompson D, Seal S et al. ATM mutations that cause ataxiatelangiectasia are breast cancer susceptibility alleles. Nat Genet 2006; 38: 873-875. doi:10.1038/ng1837 
[27] Tavtigian SV, Oefner P], Babikyan D et al. Rare, evolutionarily unlikely missense substitutions in ATM confer increased risk of breast cancer. Am J Hum Genet 2009; 85: 427-446. doi:10.1016/j.ajhg.2009.08.018

[28] Keimling M, Volcic M, Csernok A et al. Functional characterization connects individual patient mutations in ataxia telangiectasia mutated (ATM) with dysfunction of specific DNA double-strand break-repair signaling pathways. FASEB J 2011; 25: 3849-3860. doi:10.1096/fj.11185546

[29] Gilad S, Chessa L, Khosravi R et al. Genotype-phenotype relationships in ataxia-telangiectasia and variants. Am J Hum Genet 1998; 62: 551-561. doi:10.1086/301755

[30] Fernandes N, Sun Y, Chen S et al. DNA damage-induced association of ATM with its target proteins requires a protein interaction domain in the $\mathrm{N}$ terminus of ATM. J Biol Chem 2005; 280: 15158-15164. doi:10.1074/jbc.M412065200

[31] Young DB, Jonnalagadda J, Gatei M et al. Identification of domains of ataxia-telangiectasia mutated required for nuclear localization and chromatin association. J Biol Chem 2005; 280: 27587-27594. doi:10.1074/ jbc.M411689200

[32] Mitui M, Nahas SA, Du LT et al. Functional and computational assessment of missense variants in the ataxia-telangiectasia mutated (ATM) gene: mutations with increased cancer risk. Hum Mutat 2009; 30: $12-$ 21. doi:10.1002/humu.20805

[33] Tavtigian SV, Oefner P], Babikyan D et al. Rare, evolutionarily unlikely missense substitutions in ATM confer increased risk of breast cancer. Am J Hum Genet 2009; 85: 427-446. doi:10.1016/j.ajhg.2009.08.018

[34] Barone G, Groom A, Reiman A et al. Modeling ATM mutant proteins from missense changes confirms retained kinase activity. Hum Mutat 2009; 30: 1222-1230. doi:10.1002/humu.21034

[35] Southey MC, Goldgar DE, Winqvist R et al. PALB2, CHEK2 and ATM rare variants and cancer risk: data from COGS. J Med Genet 2016; 53: 800811. doi:10.1136/jmedgenet-2016-103839

[36] Khanna KK, Keating KE, Kozlov S et al. ATM associates with and phosphorylates p 53: mapping the region of interaction. Nat Genet 1998; 20 : 398-400. doi:10.1038/3882

[37] Gatei M, Scott SP, Filippovitch I et al. Role for ATM in DNA damage-induced phosphorylation of BRCA1. Cancer Res 2000; 60: 3299-3304

[38] Girard E, Eon-Marchais S, Olaso R et al. Familial breast cancer and DNA repair genes: Insights into known and novel susceptibility genes from the GENESIS study, and implications for multigene panel testing. Int J Cancer 2018. doi:10.1002/ijc.31921

[39] Catucci I, Radice P, Milne RL et al. The PALB2 p.Leu939Trp mutation is not associated with breast cancer risk. Breast Cancer Res 2016; 18: 111. doi:10.1186/s13058-016-0762-9

[40] Antoniou AC, Casadei S, Heikkinen T et al. Breast-cancer risk in families with mutations in PALB2. N Engl J Med 2014; 371: 497-506. doi:10.1056/NEJMoa1400382

[41] Antoniou AC, Foulkes WD, Tischkowitz M. Breast-cancer risk in families with mutations in PALB2. N Engl J Med 2014; 371: 1651-1652. doi:10.1056/NEJMc1410673

[42] Antoniou AC, Foulkes WD, Tischkowitz M. Breast cancer risk in women with PALB2 mutations in different populations. Lancet Oncol 2015; 16 : e375-e376. doi:10.1016/s1470-2045(15)00002-9

[43] Southey MC, Teo ZL, Dowty JG et al. A PALB2 mutation associated with high risk of breast cancer. Breast Cancer Res 2010; 12: R109. doi:10.1186/bcr2796

[44] Tischkowitz M, Capanu M, Sabbaghian N et al. Rare germline mutations in PALB2 and breast cancer risk: a population-based study. Hum Mutat 2012; 33: 674-680. doi:10.1002/humu.22022
[45] Tischkowitz M, Sabbaghian N, Hamel N et al. Contribution of the PALB2 c.2323C>T [p. Q775X] founder mutation in well-defined breast and/or ovarian cancer families and unselected ovarian cancer cases of French Canadian descent. BMC Med Genet 2013; 14: 5. doi:10.1186/14712350-14-5

[46] Obermeier K, Sachsenweger J, Friedl TW et al. Heterozygous PALB2 c.1592delT mutation channels DNA double-strand break repair into error-prone pathways in breast cancer patients. Oncogene 2016; 35: 3796-3806. doi:10.1038/onc.2015.448

[47] Hayakawa T, Zhang F, Hayakawa N et al. MRG15 binds directly to PALB2 and stimulates homology-directed repair of chromosomal breaks. J Cell Sci 2010; 123: 1124-1130. doi:10.1242/jcs.060178

[48] Sy SM, Huen MS, Chen J. MRG15 is a novel PALB2-interacting factor involved in homologous recombination. J Biol Chem 2009; 284: $21127-$ 21131. doi:10.1074/jbc.C109.023937

[49] Zhang F, Ma J, Wu J et al. PALB2 links BRCA1 and BRCA2 in the DNA-damage response. Curr Biol 2009; 19: 524-529. doi:10.1016/j.cub.2009. 02.018

[50] Foo TK, Tischkowitz M, Simhadri S et al. Compromised BRCA1-PALB2 interaction is associated with breast cancer risk. Oncogene 2017; 36: 4161-4170. doi:10.1038/onc.2017.46

[51] Buisson R, Dion-Cote AM, Coulombe Y et al. Cooperation of breast cancer proteins PALB2 and piccolo BRCA2 in stimulating homologous recombination. Nat Struct Mol Biol 2010; 17: 1247-1254. doi:10.1038/ nsmb.1915

[52] Dray E, Etchin J, Wiese $C$ et al. Enhancement of RAD51 recombinase activity by the tumor suppressor PALB2. Nat Struct Mol Biol 2010; 17: 1255-1259. doi:10.1038/nsmb. 1916

[53] Bleuyard JY, Buisson R, Masson JY et al. ChAM, a novel motif that mediates PALB2 intrinsic chromatin binding and facilitates DNA repair. EMBO Rep 2012; 13: 135-141. doi:10.1038/embor.2011.243

[54] Park JY, Singh TR, Nassar N et al. Breast cancer-associated missense mutants of the PALB2 WD40 domain, which directly binds RAD51C, RAD51 and BRCA2, disrupt DNA repair. Oncogene 2014; 33: 4803-4812. doi:10.1038/onc.2013.421

[55] Oliver AW, Swift S, Lord C] et al. Structural basis for recruitment of BRCA2 by PALB2. EMBO Rep 2009; 10: 990-996. doi:10.1038/embor. 2009.126

[56] Zhang F, Fan Q, Ren K et al. PALB2 functionally connects the breast cancer susceptibility proteins BRCA1 and BRCA2. Mol Cancer Res 2009; 7: 1110-1118. doi:10.1158/1541-7786.mcr-09-0123

[57] Caleca L, Catucci I, Figlioli G et al. Two Missense Variants Detected in Breast Cancer Probands Preventing BRCA2-PALB2 Protein Interaction. Front Oncol 2018; 8: 480. doi:10.3389/fonc.2018.00480

[58] Hellebrand H, Sutter C, Honisch E et al. Germline mutations in the PALB2 gene are population specific and occur with low frequencies in familial breast cancer. Hum Mutat 2011; 32: E2176-E2188. doi:10.1002/humu. 21478

[59] Sodha N, Williams R, Mangion J et al. Screening hCHK2 for mutations. Science 2000; 289: 359

[60] Cybulski C, Gorski B, Huzarski T et al. CHEK2 is a multiorgan cancer susceptibility gene. Am J Hum Genet 2004; 75: 1131-1135. doi:10.1086/ 426403

[61] Cai Z, Chehab NH, Pavletich NP. Structure and activation mechanism of the CHK2 DNA damage checkpoint kinase. Mol Cell 2009; 35: 818-829. doi:10.1016/j.molcel.2009.09.007

[62] Roeb W, Higgins J, King MC. Response to DNA damage of CHEK2 missense mutations in familial breast cancer. Hum Mol Genet 2012; 21: 2738-2744. doi:10.1093/hmg/dds101 
[63] Ow GS, Ivshina AV, Fuentes G et al. Identification of two poorly prognosed ovarian carcinoma subtypes associated with CHEK2 germ-line mutation and non-CHEK2 somatic mutation gene signatures. Cell Cycle 2014; 13: 2262-2280. doi:10.4161/cc.29271

[64] Muranen TA, Blomqvist C, Dork T et al. Patient survival and tumor characteristics associated with CHEK2:p. I157T - findings from the Breast Cancer Association Consortium. Breast Cancer Res 2016; 18: 98. doi:10.1186/s13058-016-0758-5

[65] Dong X, Wang L, Taniguchi $\mathrm{K}$ et al. Mutations in CHEK2 associated with prostate cancer risk. Am J Hum Genet 2003; 72: 270-280. doi:10.1086/ 346094

[66] Ahn J, Prives C. Checkpoint kinase 2 (Chk2) monomers or dimers phosphorylate $\mathrm{Cdc} 25 \mathrm{C}$ after DNA damage regardless of threonine 68 phosphorylation. J Biol Chem 2002; 277: 48418-48426. doi:10.1074/jbc. M208321200

[67] Ahn J, Urist M, Prives C. The Chk2 protein kinase. DNA Repair (Amst) 2004; 3: 1039-1047. doi:10.1016/j.dnarep.2004.03.033

[68] Schwarz JK, Lovly CM, Piwnica-Worms H. Regulation of the Chk2 protein kinase by oligomerization-mediated cis- and trans-phosphorylation. Mol Cancer Res 2003; 1: 598-609

[69] Han FF, Guo CL, Liu LH. The effect of CHEK2 variant I157T on cancer susceptibility: evidence from a meta-analysis. DNA Cell Biol 2013; 32: 329335. doi:10.1089/dna.2013.1970

[70] Kleibl Z, Havranek O, Novotny J et al. Analysis of CHEK2 FHA domain in Czech patients with sporadic breast cancer revealed distinct rare genetic alterations. Breast Cancer Res Treat 2008; 112: 159-164. doi:10.1007| s10549-007-9838-7

[71] Bak A, Janiszewska H, Junkiert-Czarnecka A et al. A risk of breast cancer in women - carriers of constitutional CHEK2 gene mutations, originating from the North - Central Poland. Hered Cancer Clin Pract 2014; 12: 10. doi:10.1186/1897-4287-12-10

[72] Kato S, Han SY, Liu W et al. Understanding the function-structure and function-mutation relationships of p 53 tumor suppressor protein by high-resolution missense mutation analysis. Proc Natl Acad Sci U S A 2003; 100: 8424-8429. doi:10.1073/pnas.1431692100

[73] Mathe E, Olivier M, Kato $S$ et al. Predicting the transactivation activity of p53 missense mutants using a four-body potential score derived from Delaunay tessellations. Hum Mutat 2006; 27: 163-172. doi:10.1002/ humu.20284

[74] Soussi T, Kato S, Levy PP et al. Reassessment of the TP53 mutation database in human disease by data mining with a library of TP53 missense mutations. Hum Mutat 2005; 25: 6-17. doi:10.1002/humu.20114

[75] Leroy B, Fournier JL, Ishioka C et al. The TP53 website: an integrative resource centre for the TP53 mutation database and TP53 mutant analysis. Nucleic Acids Res 2013; 41: D962-D969. doi:10.1093/nar/gks1033

[76] Monti P, Ciribilli Y, Jordan J et al. Transcriptional functionality of germ line p 53 mutants influences cancer phenotype. Clin Cancer Res 2007; 13 : 3789-3795. doi:10.1158/1078-0432.ccr-06-2545

[77] Monti P, Perfumo C, Bisio A et al. Dominant-negative features of mutant TP53 in germline carriers have limited impact on cancer outcomes. Mol Cancer Res 2011; 9: 271-279. doi:10.1158/1541-7786.mcr-10-0496

[78] Saha T, Kar RK, Sa G. Structural and sequential context of p 53: A review of experimental and theoretical evidence. Prog Biophys Mol Biol 2015; 117: 250-263. doi:10.1016/j.pbiomolbio.2014.12.002

[79] Buchhop S, Gibson MK, Wang XW et al. Interaction of p 53 with the human Rad51 protein. Nucleic Acids Res 1997; 25: 3868-3874

[80] Liang SH, Clarke MF. The nuclear import of p 53 is determined by the presence of a basic domain and its relative position to the nuclear localization signal. Oncogene 1999; 18: 2163-2166. doi:10.1038/sj.onc. 1202350

[81] Shaulsky G, Goldfinger N, Ben-Ze'ev A et al. Nuclear accumulation of p 53 protein is mediated by several nuclear localization signals and plays a role in tumorigenesis. Mol Cell Biol 1990; 10: 6565-6577
[82] Linke SP, Sengupta S, Khabie N et al. p53 interacts with hRAD51 and hRAD54, and directly modulates homologous recombination. Cancer Res 2003; 63: 2596-2605

[83] Pittman DL, Weinberg LR, Schimenti JC. Identification, characterization, and genetic mapping of Rad51 d, a new mouse and human RAD51/ RecA-related gene. Genomics 1998; 49: 103-111. doi:10.1006/geno. 1998.5226

[84] Cartwright R, Dunn AM, Simpson PJ et al. Isolation of novel human and mouse genes of the recA/RAD51 recombination-repair gene family. Nucleic Acids Res 1998; 26: 1653-1659

[85] Rivera B, Di lorio M, Frankum J et al. Functionally Null RAD51D Missense Mutation Associates Strongly with Ovarian Carcinoma. Cancer Res 2017; 77: 4517-4529. doi:10.1158/0008-5472.Can-17-0190

[86] Kim YM, Choi BS. Structural and functional characterization of the N-terminal domain of human Rad51D. Int J Biochem Cell Biol 2011; 43: 416422. doi:10.1016/j.biocel.2010.11.014

[87] Gruver AM, Miller KA, Rajesh C et al. The ATPase motif in RAD51D is required for resistance to DNA interstrand crosslinking agents and interaction with RAD51C. Mutagenesis 2005; 20: 433-440. doi:10.1093/ mutage/gei059

[88] Gutierrez-Enriquez S, Bonache S, de Garibay GR et al. About 1\% of the breast and ovarian Spanish families testing negative for BRCA1 and BRCA2 are carriers of RAD51D pathogenic variants. Int J Cancer 2014; 134: 2088-2097. doi:10.1002/ijc.28540

[89] Janatova M, Soukupova J, Stribrna J et al. Mutation Analysis of the RAD51C and RAD51D Genes in High-Risk Ovarian Cancer Patients and Families from the Czech Republic. PLoS One 2015; 10: e0127711. doi:10.1371/journal.pone.0127711

[90] Thompson ER, Rowley SM, Sawyer S et al. Analysis of RAD51D in ovarian cancer patients and families with a history of ovarian or breast cancer. PLoS One 2013; 8: e54772. doi:10.1371/journal.pone.0054772

[91] Miller KA, Sawicka D, Barsky D et al. Domain mapping of the Rad51 paralog protein complexes. Nucleic Acids Res 2004; 32: 169-178. doi:10.1093/nar/gkg925

[92] Loveday C, Turnbull C, Ramsay E et al. Germline mutations in RAD51D confer susceptibility to ovarian cancer. Nat Genet 2011; 43: 879-882. doi:10.1038/ng.893

[93] Wiese C, Hinz JM, Tebbs RS et al. Disparate requirements for the Walker A and B ATPase motifs of human RAD51D in homologous recombination. Nucleic Acids Res 2006; 34: 2833-2843. doi:10.1093/nar/gkl366

[94] Song H, Dicks E, Ramus S] et al. Contribution of Germline Mutations in the RAD51B, RAD51C, and RAD51D Genes to Ovarian Cancer in the Population. J Clin Oncol 2015; 33: 2901-2907. doi:10.1200/jco.2015.61. 2408

[95] Meindl A, Hellebrand H, Wiek C et al. Germline mutations in breast and ovarian cancer pedigrees establish RAD51C as a human cancer susceptibility gene. Nat Genet 2010; 42: 410-414. doi:10.1038/ng.569

[96] Vaz F, Hanenberg $\mathrm{H}$, Schuster B et al. Mutation of the RAD51C gene in a Fanconi anemia-like disorder. Nat Genet 2010; 42: 406-409. doi:10.1038/ng.570

[97] Clague J, Wilhoite G, Adamson A et al. RAD51C germline mutations in breast and ovarian cancer cases from high-risk families. PLoS One 2011; 6: e25632. doi:10.1371/journal.pone.0025632

[98] Osorio A, Endt D, Fernandez F et al. Predominance of pathogenic missense variants in the RAD51C gene occurring in breast and ovarian cancer families. Hum Mol Genet 2012; 21: 2889-2898. doi:10.1093/hmg/ dds 115

[99] French CA, Tambini CE, Thacker ]. Identification of functional domains in the RAD51L2 (RAD51C) protein and its requirement for gene conversion. J Biol Chem 2003; 278: 45445-45450. doi:10.1074/jbc. M308621200 
[100] Jonson L, Ahlborn LB, Steffensen AY et al. Identification of six pathogenic RAD51C mutations via mutational screening of 1228 Danish individuals with increased risk of hereditary breast and/or ovarian cancer. Breast Cancer Res Treat 2016; 155: 215-222. doi:10.1007/s10549015-3674-y

[101] Schnurbein G, Hauke J, Wappenschmidt B et al. RAD51C deletion screening identifies a recurrent gross deletion in breast cancer and ovarian cancer families. Breast Cancer Res 2013; 15: R120. doi:10.1186/bcr3589

[102] Ali AM, Singh TR, Meetei AR. FANCM-FAAP24 and FANC): FA proteins that metabolize DNA. Mutat Res 2009; 668: 20-26. doi:10.1016/j. mrfmmm.2009.04.002

[103] Yu X, Chini CC, He M et al. The BRCT domain is a phospho-protein binding domain. Science 2003; 302: 639-642. doi:10.1126/science. 1088753

[104] Peng M, Litman R, Xie J et al. The FANC]/MutLalpha interaction is required for correction of the cross-link response in FA-J cells. EMBO J 2007; 26: 3238-3249. doi:10.1038/sj.emboj.7601754

[105] Weber-Lassalle N, Hauke J, Ramser ] et al. BRIP1 loss-of-function mutations confer high risk for familial ovarian cancer, but not familial breast cancer. Breast Cancer Res 2018; 20: 7. doi:10.1186/s13058-018-09359

[106] Castera L, Harter V, Muller E et al. Landscape of pathogenic variations in a panel of 34 genes and cancer risk estimation from 5131 HBOC families. Genet Med 2018. doi:10.1038/s41436-018-0005-9

[107] Li J, Meeks H, Feng BJ et al. Targeted massively parallel sequencing of a panel of putative breast cancer susceptibility genes in a large cohort of multiple-case breast and ovarian cancer families. J Med Genet 2016; 53: 34-42. doi:10.1136/jmedgenet-2015-103452
[108] Norquist BM, Harrell MI, Brady MF et al. Inherited Mutations in Women With Ovarian Carcinoma. JAMA Oncol 2016; 2: 482-490. doi:10.1001/ jamaoncol.2015.5495

[109] Ramus SJ, Song H, Dicks E et al. Germline Mutations in the BRIP1, BARD1, PALB2, and NBN Genes in Women With Ovarian Cancer. J Natl Cancer Inst 2015; 107: pii: djv214. doi:10.1093/jnci/djv214

[110] Lilyquist J, LaDuca $\mathrm{H}$, Polley E et al. Frequency of mutations in a large series of clinically ascertained ovarian cancer cases tested on multigene panels compared to reference controls. Gynecol Oncol 2017; 147: 375-380. doi:10.1016/j.ygyno.2017.08.030

[111] Hansford S, Kaurah P, Li-Chang $\mathrm{H}$ et al. Hereditary Diffuse Gastric Cancer Syndrome: CDH1 Mutations and Beyond. JAMA Oncol 2015; 1: 23 32. doi:10.1001/jamaoncol.2014.168

[112] Melo S, Figueiredo J, Fernandes MS et al. Predicting the Functional Impact of $\mathrm{CDH} 1$ Missense Mutations in Hereditary Diffuse Gastric Cancer. Int J Mol Sci 2017; 18: pii: E2687. doi:10.3390/ijms18122687

[113] Oliveira C, Pinheiro H, Figueiredo J et al. Familial gastric cancer: genetic susceptibility, pathology, and implications for management. Lancet Oncol 2015; 16: e60-e70. doi:10.1016/S1470-2045(14)71016-2

[114] Corso G, Intra M, Trentin C et al. CDH1 germline mutations and hereditary lobular breast cancer. Fam Cancer 2016; 15: 215-219. doi:10.1007/s10689-016-9869-5

[115] Krempely K, Karam R. A novel de novo $C D H 1$ germline variant aids in the classification of carboxy-terminal E-cadherin alterations predicted to escape nonsense-mediated mRNA decay. Cold Spring Harb Mol Case Stud 2018; 4: pii: a003012. doi:10.1101/mcs.a003012

[116] Matsuoka S, Rotman G, Ogawa A et al. Ataxia telangiectasia-mutated phosphorylates Chk2 in vivo and in vitro. Proc Natl Acad Sci U S A 2000; 97: 10389-10394. doi:10.1073/pnas.190030497 